\title{
A glass spherule of questionable impact origin from the Apollo 15 landing site: Unique target mare basalt
}

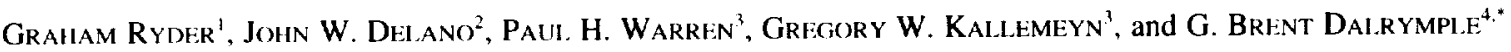 \\ 'Lunar and Planetary Institute, Center for Advanced Space Studies, 3600 Bay Area Boulevard, Houston. TX 77058-11 13, USA \\ 'Department of Geological Sciences, State University of New York, Albany, NY 12222, USA \\ 'Institute of Geophysics and Planetary Physics, University of California, Los Angeles, CA 90024-1567, USA \\ ${ }^{4}$ United States Geological Survey, 345 Middlefield Road, Menlo Park, CA 94025, USA
}

(Received April 13, 1995; accepted in revised form November 11, 1995)

\begin{abstract}
A 6 mm-diameter dark spherule, 15434,28, from the regolith on the Apennine Front at the Apollo 15 landing site has a homogeneous glass interior with a $200 \mu \mathrm{m}$-thick rind of devitrified or crystallized melt. The rind contains abundant small fragments of Apollo 15 olivine-normative mare basalt and rare volcanic Apollo 15 green glass. The glass interior of the spherule has the chemical composition, including a high $\mathrm{FeO}$ content and high $\mathrm{CaO} / \mathrm{Al}_{2} \mathrm{O}_{3}$, of a mare basalt. Whereas the major element and $\mathrm{Sc}$, $\mathrm{Ni}$, and $\mathrm{Co}$ abundances are similar to those of low-Ti mare basalts, the incompatible elements and $\mathrm{Sr}$ abundances are similar to those of high-Ti mare basalts. The relative abundance patterns of the incompatible trace elements are distinct from any other lunar mare basalts or KREEP; among these distinctions are a much steeper slope of the heavy rare earth elements. The 15434,28 glass has abundances of the volatile element $\mathrm{Zn}$ consistent with both impact glasses and crystalline mare basalts, but much lower than in glasses of mare volcanic origin. The glass contains siderophile elements such as Ir in abundances only slightly higher than accepted lunar indigenous levels, and some, such as Au, are just below such upper limits. The age of the glass, determined by the ${ }^{410} \mathrm{Ar} /{ }^{39} \mathrm{Ar}$ laser incremental heating technique, is $1647 \pm 11 \mathrm{Ma}(2 \sigma)$; it is expressed as an age spectrum of seventeen steps over $96 \%$ of the ${ }^{39} \mathrm{Ar}$ released, unusual for an impact glass. Trapped argon is negligible. The undamaged nature of the sphere demonstrates that it must have spent most of its life buried in regolith; ${ }^{18} \mathrm{Ar}$ cosmic ray exposure data suggest that it was buried at less than $2 \mathrm{~m}$ but more than a few centimeters if a single depth is appropriate. That the spherule solidified to a glass is surprising; for such a mare composition, cooling at about $50^{\circ} \mathrm{C} \mathrm{s}^{-1}$ is required to avoid crystallization, and barely attainable in such a large spherule. The low volatile abundances, slightly high siderophile abundances, and the young age are perhaps all most consistent with an impact origin, but nonetheless not absolutely definitive.

The 15434,28 glass is distinct from the common yellow impact glasses at the Apollo 15 landing site, in particular in its lower abundances of incompatible elements and much younger age. If we accept an impact origin, then the trace element relative abundances preclude both typical KREEP and the common Apollo 15 yellow impact glass from contributing more than a few percent of the incompatible elements to potential mixtures. The melted part of any target must have consisted almost entirely of a variety (or varieties) of mare basalt or glass distinct from any known mare basalts or glasses, including Apollo 15 yellow volcanic glass, or mixtures of them. However, the rind inclusions, similar to materials of local origin, do suggest a source near the Apollo 15 landing site. An impact melt cannot have dissolved much, if any, of such inclusions. A lack of regolith materials in the rind and in the melt component suggest an immature source terrain. Thus, even for an impact origin, there is the possibility (though not requirement) that the volcanic target is younger than most mare plains. The crater Hadley $C, 25 \mathrm{~km}$ away, is a potential source. If the 15434,28 glass is instead directly of volcanic origin, it represents an extremely young mare magma of a type previously undiscovered on the Moon.
\end{abstract}

\section{INTRODUCTION}

A $6 \mathrm{~mm}$ knobby dark spherule (Fig. 1) is one of the particles of coarse fines (4-10 mm) separated from regolith sample 15430 collected at Station 7 at Spur Crater on the Apennine Front on the Apollo 15 mission. The sample was part of the pedestal on which anorthosite 15415 ("genesis rock") was perched. The $390 \mathrm{mg}$ spherule was included in a group of twenty-six glass and glass-rich particles $(15434,1)$ separated and described by Powell (1972). The spherule was numbered 15434,28 . Its surface was dark gray.

* Present address: College of Oceanic and Atmospheric Sciences, Oceanography Admin. Bld. 104, Oregon State University. Corvallis, OR 97.331-5503, USA
In 1972 a chip of 15434,28 was taken for thin sections. Phinney et al. (1972) described the fragment from thin section , 130 as one of several orange-brown glasses having mare basalt compositions; they published a microprobe analysis of the glass, which is similar to microprobe analyses made later by D. T. Vaniman and J. J. Papike (pers. commun.) and in the present study (Table 1, which also lists analyses of Apollo 15 yellow volcanic and impact glasses). The analyses show that the glass has a mare basalt composition distinct from the local mare basalts in its higher $\mathrm{TiO}_{2}$ and $\mathrm{K}_{2} \mathrm{O}$ abundances. The sample was ignored until the present study, possibly because the major element chemical composition of the glass is roughly similar to that of other Apollo 15 impact glasses (although these latter generally have still higher $\mathrm{TiO}_{2}$ abundances), and 


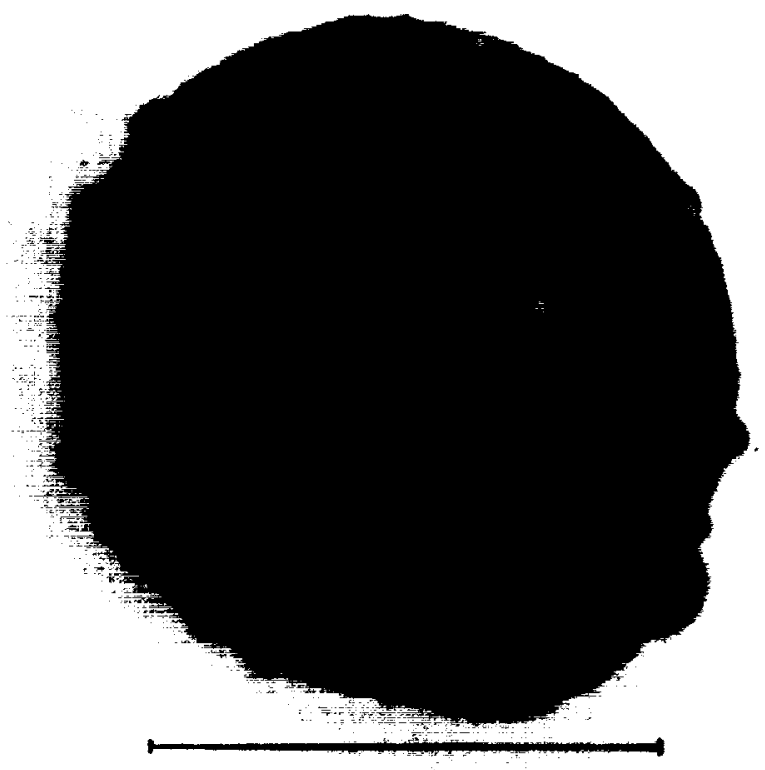

Fici. 1. Image of spherule 15434,28 prior to its dissection. Scale bar $5 \mathrm{~mm}$ (NASA photo S-71-59627).

because the presence of inclusions was suggestive of an impact origin.

The present study was started when a piece of 15434,28 was accidentally allocated for chemical analysis because of an Apollo-era curatorial sample misnumbering during the thin section making (this misnumbering applies to the Phinney et al., 1972, report, where the sample is listed as 15434,48 instead of ,28). Details of the sample numbering history are in Ryder and Sherman (1989). The analysis for major and trace elements confirmed that the spherule was distinct from other lunar materials, and the binocular inspection revealed that the inclusions were confined to a narrow rind surrounding a homogeneous glass interior. These characteristics suggested that the glass might be of volcanic origin, or if of impact origin was physically and chemically unusual with an unusual source (Ryder, 1990a,b). Thus, further determinations of the trace element chemical composition, by synchrotron $\mathrm{X}$-ray fluorescence and radiochemical neutron activation, and the age, by ${ }^{40} \mathrm{Ar} /{ }^{39} \mathrm{Ar}$ laser incremental heating techniques, were made in an attempt to better understand the origin of the spherule.

Our data are most consistent with the conclusion that the spherule was derived by an impact into an immature (regolithpoor) mare basalt terrain chemically distinct from any analyzed mare basalts. Nonetheless, an origin as a distinct and unusual mare eruption cannot be precluded. The spherule cooled extremely quickly and fragments of local olivine-normative mare basalt and volcanic green glass adhered to its exterior. The vent or impact target was probably near the Apollo 15 landing site.

\section{GENERAL CHARACTERISTICS OF SPHERULE 15434,28}

15434,28 is the only spherule separated from the coarse fines of 15430 and described by Powell (1972). He described the sphere as having a dark color and a knobby surface. The split allocated for our study has an exterior surface that is dark gray and slightly bumpy or blistered; scattered mineral and lithic fragments are embedded in it. One $2 \mathrm{~mm}$ lithic fragment that protrudes from the surface is of a mare basalt. The discrete mineral fragments are mainly pyroxene and olivine, with some plagioclase. The embedded lithic and mineral fragments have clean surfaces, lacking adhering dust, splashed glass, or patina. The interior is a homogeneous black glass (orangebrown in thin flakes) with a conchoidal fracture; it lacks banding, vesicles, crystals or crystallites, inclusions, or metal blebs. In contrast, the outer 150 to $250 \mu \mathrm{m}$ is duller, as if devitrified. The boundary between this rind and the glass interior is fairly sharp.

In 1972 a chip was taken and two parallel thin sections made from it. One thin section $(, 130)$ is over-representative of the rind (Fig. 2a); the other $(, 131)$ is almost all interior glass. The interior glass is yellow or pale orange in thin section, and optically homogeneous. It has cracks that might be an artifact of thin sectioning. The rind, ranging from about $150-250 \mu \mathrm{m}$ thick, consists of about 40 vol\% inclusions and about 60 vol\% fine-grained crystallized or devitrified melt. Elongate and dendritic crystallites of olivine nucleated preferentially on the inclusions (Fig. 2b). These crystals are generally smallest close to the inclusions. Most of the inclusions are less than $200 \mu \mathrm{m}$ in maximum dimension.

The transition from the fine-grained rind to the glassy interior is fairly sharp (Fig. 2a,c) but does not have the abrupt characteristics of devitrification fronts found in many lunar glasses. The rind is not a separately added entity (thus rind might not be the appropriate terminology), and its crystallization characteristics were probably produced by the addition of cold inclusions. Most melt spherules might be expected to have crystallites in the interior and a glass at the exterior, the

TABLE 1. Microprobe analyses of 15434,28,131 glass sphere and other Apollo 15 yellow glasses.

\begin{tabular}{lccccc}
\hline & $\mathrm{A}$ & $\mathrm{B}$ & $\mathrm{C}$ & $\mathrm{D}$ & $\mathrm{E}$ \\
\hline $\mathrm{wvG}$ & & & & & \\
$\mathrm{SiO}_{2}$ & 43.7 & 42.6 & 43.3 & 45.6 & 42.9 \\
$\mathrm{TiO}_{2}$ & 3.6 & 3.5 & 3.5 & 4.1 & 3.5 \\
$\mathrm{Al}_{2} \mathrm{O}_{3}$ & 9.7 & 9.3 & 9.3 & 9.2 & 8.3 \\
$\mathrm{Cr}_{2} \mathrm{O}_{3}$ & 0.46 & & 0.48 & 0.34 & 0.59 \\
$\mathrm{FeO}$ & 21.3 & 21.0 & 20.9 & 20.4 & 22.1 \\
$\mathrm{MnO}$ & 0.2 & & 0.3 & 0.28 & 0.27 \\
$\mathrm{MgO}$ & 11.2 & 10.3 & 10.5 & 9.5 & 13.5 \\
$\mathrm{CaO}$ & 9.0 & 9.2 & 8.7 & 8.9 & 8.5 \\
$\mathrm{Na}_{2} \mathrm{O}$ & 0.68 & 0.74 & 0.66 & 0.27 & 0.45 \\
$\mathrm{~K}_{2} \mathrm{O}$ & 0.15 & 0.14 & 0.14 & 0.21 & \\
$\mathrm{P}_{2} \mathrm{O}$ & & 0.43 & & 0.18 & \\
$\mathrm{Sum}_{5}$ & 99.9 & 97.3 & 97.8 & 99.0 & 100.1 \\
\hline
\end{tabular}

15434,28,131: (A) This study (B) Phinney et al, 1972

(C) Vaniman and Papike. pers. comm.

A15 Yellow impact glass 15010: (D) Taylor et al. (1980) A 15 Yellow volcanic glass: (E) Delano (1986) 
opposite of spherule 15434,28. Neither volcanic glassy spherules from the Moon (such as Apollo 15 green glasses; Basu et al., 1979) and Earth (such as those at Kilaeua Iki; Heiken, 1972), nor recognized impact glassy spherules from the Moon have similar rinds.

\section{ANALYTICAL METHODS}

Electron microprobe analyses for major element abundances in the glass interior were made on thin section ,131 on the Cameca micro- probe at the Johnson Space Center using standard procedures and techniques. An accelarating voltage of $15 \mathrm{kV}$ and a beam current of $25 \mathrm{nA}$ was used. The beam was focussed. Kaersutite was the standard for all elements except $\mathrm{Cr}$ (a chromite), $\mathrm{Mn}$ (a garnet), and $\mathrm{P}$ (apatite). The glass is homogeneous and the average of twenty analyses are listed in Table 1, Column A. Similar conditions were used for microprobe analyses of mineral inclusions in the rind.

A $144 \mathrm{mg}$ sample of chipped glass spherule was acquired. It consisted of one $67 \mathrm{mg}$ fragment (,202A) of apparently pure glass lacking rind or inclusions, and a $77 \mathrm{mg}$ fragment $(, 202 \mathrm{~B})$ consisting of glass with obvious rind and inclusions.

TABLE 2. Chemical analyses of $15434,28,202$ and other A15 yellow glasses.

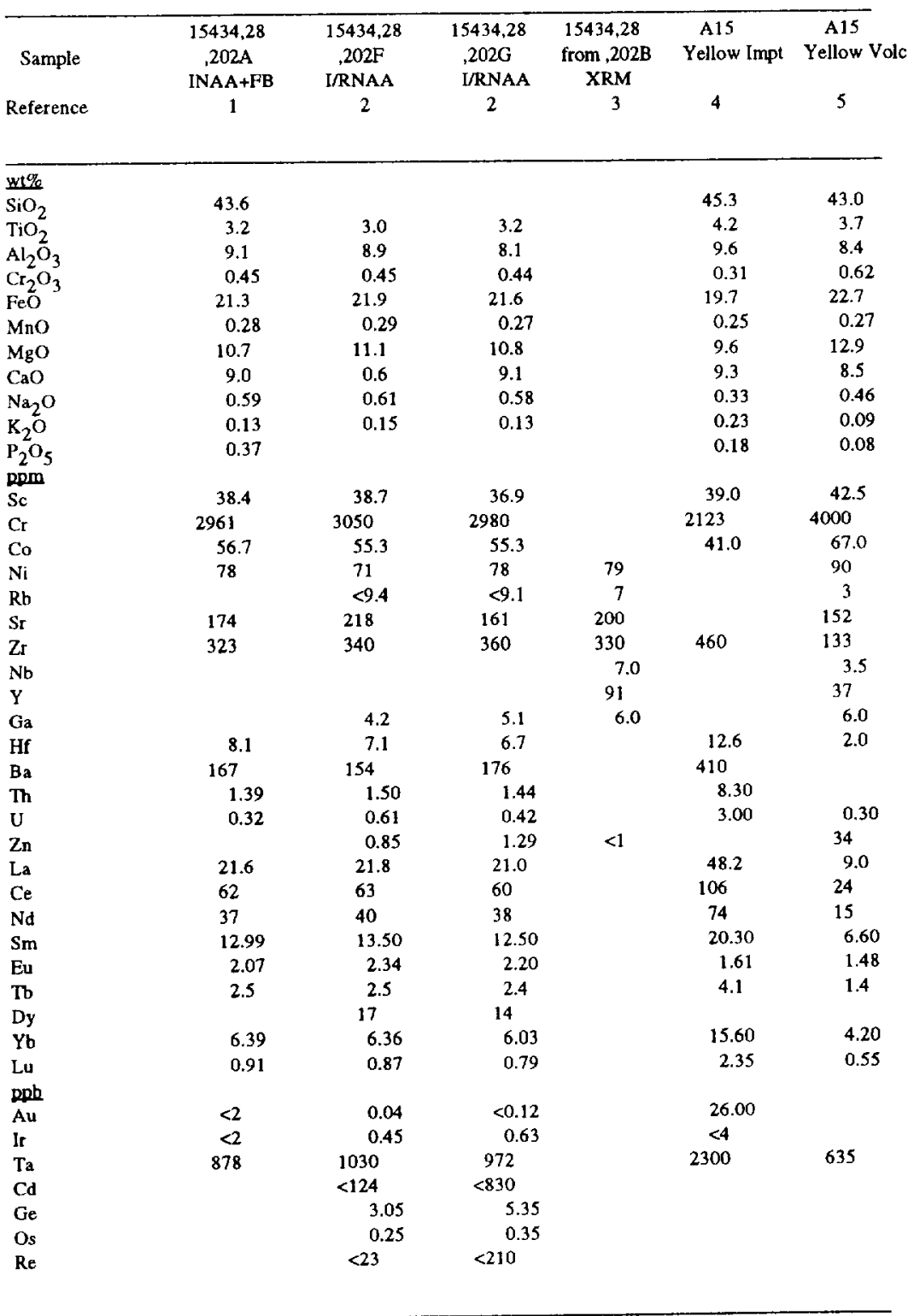

NAA: Instrumental neutron activation.

RNAA: Radiochemical neutron activation.

FB: Microprobe, fused bead.

XRM: Synchrotron $X$-ray fluorescence.

1) This study, Johnson Space Center.

2) This study, U. California, Los Angeles.

3) This study, Brookhaven.

4) Delano et al. (1982)

5) Delano (1980); Delano and Livi (1981). 

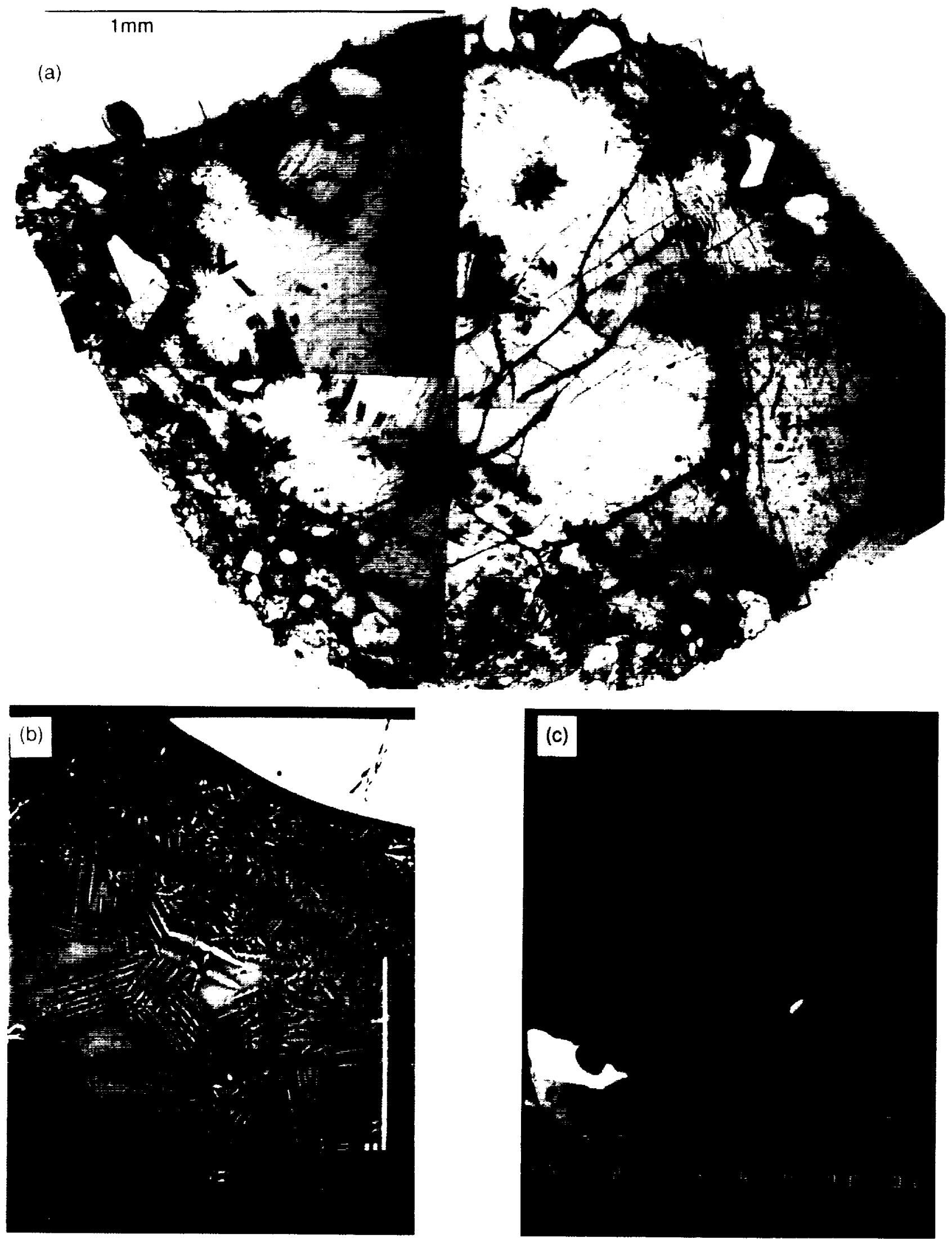
Sample .202A of the interior glass was ground into a fine powder and a $25 \mathrm{mg}$ split analyzed by instrumental neutron activation analysis using standard procedures and data reduction at the NASA Johnson Space Center (c.g.. Lindstrom et al., 1989). About $15 \mathrm{mg}$ of the same powder was re-fused into glass and analyzed for major elements by electron microprobe at the NASA Johnson Space Center using standard techniques. Neutron activation analyses were made at UCLA on $15 \mathrm{mg}$ of clear interior glass $(, 202 \mathrm{~F})$ and $11 \mathrm{mg}$ of glass with rind (,202G), both picked from ,202B, using radiochemical techniques to determine trace siderophile and volatile elements (Warren et al., 1986). Because of the small masses used, results for some elements are not as precise as normal. Nonetheless, where interla boratory comparisons can be made within this study, the data agree well.

Three tiny particles of pure glass with a total mass of $1.4 \mathrm{mg}$ were picked from ,202B and selected trace elements were determined using the synchrotron X-ray microprobe at the National Synchrotron Light Source at Brookhaven National Laboratory, NY. Sample preparation, operational conditions, and data reduction were similar to those described in Delano et al. (1991) for lunar volcanic glasses. Nickel, Rb, $\mathrm{Sr}, \mathrm{Ga}, \mathrm{Y}, \mathrm{Zr}$. Nb, and $\mathrm{Zn}$ concentrations were obtained for two areas of the interior glass and averaged. The minimum detection limit was about 1 ppm for all the elements reported. Where comparison can be made with data from other methods. the data generally agree well (Ni, Zn, Zr, and $\mathrm{Sr}$ ).

The data for major and trace elements are listed in Table 2, with other Apollo 15 yellow glass analyses for comparison.

A shard of glass $(1.38 \mathrm{mg}$ ) from the interior of the spherule $(, 202 \mathrm{~B})$ was irradiated for $112 \mathrm{~h}$ in the core of the Omega West reactor at Los Alamos National Laboratory, where it received an integrated neutron dose of approximately $2.4 \times 10^{\prime \prime \prime} n v t$. MMhb-1 hornblende (513.9 Ma. Lanphere et al., 1990) was used as the monitor mineral. The neutron efficiency factor, $J$, for the glass shard is known to a precision of approximately $0.5 \%$.

The ${ }^{* 0} \mathrm{Ar} /{ }^{31} \mathrm{Ar}$ age spectrum measurements (Table 3) were made with the GLM laser system, which consists of a 5-watt continuous argon ion laser, beam-steering and focusing optics, a small sample chamber, Ar-Zr and Zr-V-Fe getters, and a Mass Analyzer Products Model 216 mass spectrometer equipped with a Baur-Signer source and 20-stage electron multiplier. The glass shard was heated for $60 \mathrm{~s}$ at each temperature by directing the broadened (slightly defocussed) laser beam through the sapphire window of the sample chamber. Temperature up to $1200^{\circ} \mathrm{C}$ was monitored during heating with a Minarad Model MR-100 infrared microscopic radiometer, which measures temperature over a $35 \mu \mathrm{m}$ diameter spot on the sample. The emissivity was estimated at 0.87 , so the indicated sample temperatures are not necessarily accurate. Above $1200^{\circ} \mathrm{C}$ the argon release was controlled by incrementing the laser power. Corrections for interfering argon isotopes produced by undesirable reactions with calcium and potassium were determined using optical-grade $\mathrm{CaF}_{2}$ and artificial kalsilite glass (Table 3 footnote). Corrections for trapped argon are the solar values, and those for cosmogenic argon isotopes are from Hohenberg et al. (1978); atmospheric argon is assumed to be negligible. The potential errors in the ages introduced by all of these corrections are negligible $(<0.1 \%)$. The equipment and methods are those discussed in more detail by Dalrymple and Duffield (1988), Dalrymple (1989), and Dalrymple and Ryder (1993).

\section{ChEMICAL COMPOSITION OF THE GLASS}

\subsection{Major Elements}

The several major element analyses are consistent with each other, except that the fused bead shows a little lower titanium (Tables 1,2 ). The composition is that of a mare basalt; in particular, the high $\mathrm{FeO}$ abundance of $21 \mathrm{wt} \%$ (Fig. $3 \mathrm{a}, \mathrm{b})$ is characteristic of a mare hasalt. The glass is not an aluminous mare basalt and its $\mathrm{CaO} / \mathrm{Al}_{2} \mathrm{O}_{3}$ is low like typical mare basalts; it is unlike any volcanic KREEP or pristine highlands igneous rocks (Fig. 3b,c). Soils developed on mare terrains tend to have lower $\mathrm{FeO}$ and higher $\mathrm{Al}_{2} \mathrm{O}_{3}$ abundances than the local basalts because of admixture of non-mare materials, except where extremely immature near fresh bedrock (e.g., regolith sample 15530 from the edge of the rille at Apollo 15 Station $9 \mathrm{a}$, which has $20.7 \mathrm{wt} \% \mathrm{FeO}$ and $9.9 \mathrm{wt} \%$ $\mathrm{Al}_{2} \mathrm{O}_{3}$; Wänke et al., 1973). The major element composition of 15434,28 glass is generally within the spectrum of other low- $\mathrm{TiO}_{2}$ mare-like glasses from the Apollo 15 landing site (Fig. 3). It is very similar to the Apollo 15 yellow volcanic glass (Delano, 1980; Delano and Livi, 1981) except for its being slightly richer in $\mathrm{K}_{2} \mathrm{O}$ and poorer in $\mathrm{MgO}$ (Fig. 3d) and $\mathrm{Cr}_{2} \mathrm{O}_{3}$. It is similar to the common Apollo 15 yellow impact glass (Delano et al., 1982) except for having higher $\mathrm{FeO}$ and lower $\mathrm{K}_{2} \mathrm{O}$ contents. The $\mathrm{TiO}_{2}$ and $\mathrm{K}_{2} \mathrm{O}$ abundances are distinctly higher than the local olivine-normative mare basalts, which are otherwise reasonably similar in major element composition. 15434,28 is quite distinct from other lunar mare basalts of similar $\mathrm{TiO}_{2}$ content, such as the Luna 16 aluminous basalts. No other analyzed lunar mare lava or basalt is exactly like the 15434,28 glass in major element chemical composition. Alone, the major element composition suggests that the 15434,28 glass represents either a volcanic mare magma or an impact melt of a mare basalt source lacking significant admixture of highlands materials.

\subsection{Trace Incompatible and Transition Metal Elements}

The trace elements show that 15434,28 is of mare basalt composition, uncontaminated (or negligibly contaminated) with KREEP or other highlands materials. This composition is nonetheless distinct in relative trace element abundance patterns from other mare basalts so far analyzed, including the Apollo 15 yellow volcanic glass (e.g., REEs, Figs. 4, 5). Whereas the major element, Sc (Fig. 6a,b), Ni, and $\mathrm{Co}$ abundances are in the range of those of low-Ti mare basalts, the incompatible element and $\mathrm{Sr}$ abundances (Fig. 6c-e) are in the range of those of high-Ti mare basalts. The incompatible elements have higher abundances than in other mare basalts of similarly high Mg-content (Fig. 6f).

The REEs are shown in Fig. 4 with comparison with other Junar mare magmas. One set of diagrams normalizes all data to $\mathrm{Cl}$ chondrites, and the other normalizes data for mare basalts to one of the 15434,28 glass analyses of this study. The general abundance range is within that of high-Ti mare basalts (Fig. 4c,d) and higher REE members of the Luna 16 and Apollo 14 high-alumina mare hasalts (Fig. $4 \mathrm{e}-\mathrm{h}$ ). It is higher than those of low-Ti mare basalts (Fig. $4 \mathrm{a}-\mathrm{d}$ ). The relative

Fici. 2. (a) Photomicrograph of whole thin section 15434,28,130, transmitted light. Interior glass is clear; rim is fragment-bearing and crystallized or devitrified. Largest fragment (right) is a zoned Fe-rich clinopyroxene. (b) Microprobe back-scattered electron image of part of $15434,28,130$, with dendritic olivine crystallites nucleated on mafic inclusion (top right), grading into clear glass. Longest scale bar is $100 \mu \mathrm{m}$. (c) SEM image of chip of 15434,28 , showing rind/interior transition and fragments in the rind. The white fragment is an ilmenite with an unusual K-Al-Si inclusion with $\mathrm{Ca}-\mathrm{P}$ blebs. The other large fragment is a pigeonite. Scale bar is $100 \mu \mathrm{m}$. 
TABLE 3. Analytical data for ${ }^{40} \mathrm{Ar} /{ }^{39} \mathrm{Ar}$ age spectrum on Apollo 15 glass spherule 15434,28 (subsample, 202).

\begin{tabular}{|c|c|c|c|c|c|c|c|}
\hline $\begin{array}{l}\text { Temp. }{ }^{40} \mathrm{Ar} /{ }^{39} \mathrm{Ar} \\
\left({ }^{\circ} \mathrm{C}\right)\end{array}$ & ${ }^{38} \mathrm{Ar} /{ }^{39} \mathrm{Ar}$ & ${ }^{37} \mathrm{Ar} /{ }^{39} \mathrm{Ar}{ }^{b}$ & ${ }^{36} \mathrm{Ar} /{ }^{39} \mathrm{Arb}$ & $\mathrm{K} / \mathrm{Ca}$ & $\begin{array}{c}{ }^{40} \mathrm{Ar} \\
(10-14 \mathrm{~mol})\end{array}$ & (\% of total) & $\begin{array}{l}\mathrm{Age}^{\mathrm{c}} \\
(\mathrm{Myr})\end{array}$ \\
\hline
\end{tabular}

Glass fragment $(1.378 \mathrm{mg}), \mathrm{J}=0.07494$. Total gas age $=1660 \pm 11 \mathrm{Ma}(2 \mathrm{O})$

\begin{tabular}{|c|c|c|c|c|c|c|c|c|}
\hline 550 & 278.3 & 0567 & 34.8 & 1.122 & 0.014 & 0.19 & $<0.01$ & $5600 \pm 541$ \\
\hline 600 & 90.5 & 0.357 & 162.0 & 0.653 & 0.0027 & 0.014 & $<0.01$ & $3877 \pm 2380$ \\
\hline 650 & 178.8 & 0.409 & 198.1 & 0.1816 & 0.0021 & 0.047 & $<0.01$ & $5054 \pm 1476$ \\
\hline 700 & 111.9 & 0.438 & 5.75 & 0.450 & 0.085 & 0.17 & 0.01 & $4042 \pm 211$ \\
\hline 750 & 637 & 0.278 & 4.49 & 0.2677 & 0.11 & 0.35 & 0.04 & $3166 \pm 54$ \\
\hline 800 & 29.73 & 0.335 & 28.51 & 0.2586 & 0.017 & 0.62 & 0.1 & $2136 \pm 13$ \\
\hline 850 & 19.90 & 0.297 & 26.57 & 0.1996 & 0.018 & 386 & 13 & $1666 \pm 3$ \\
\hline 900 & 20.14 & 0.308 & 28.93 & 0.2074 & 0.017 & 199 & 0.6 & $.1681 \pm 3$ \\
\hline 950 & 20.77 & 0.312 & 24.94 & 0.1865 & 0.019 & 0.70 & 0.2 & $1712 \pm 7$ \\
\hline 1000 & 20.44 & 0.301 & 24.20 & 0.1940 & 0.020 & 1.12 & 0.4 & $1693 \pm 5$ \\
\hline 1050 & 20.03 & 0.305 & 27.92 & 0.2022 & 0.017 & 3.09 & 1.0 & $1674 \pm 3$ \\
\hline 1100 & 19.60 & 0.304 & 27.74 & 0.2032 & 0.017 & 8.98 & 3.0 & $1651 \pm 3$ \\
\hline 1125 & 19.65 & 0.302 & 27.52 & 0.1999 & 0.018 & 5.48 & 1.8 & $1653 \pm 3$ \\
\hline 1150 & 19.52 & 0.307 & 26.75 & 0.2031 & 0.018 & 3.54 & 1.2 & $1646 \pm 3$ \\
\hline 1175 & 19.46 & 0.308 & 26.93 & 0.1951 & 0.018 & 3.64 & 1.2 & $1642 \pm 3$ \\
\hline 1200 & 19.42 & 0.300 & 27.10 & 0.1996 & 0.018 & 4.60 & 1.6 & $1640 \pm 3$ \\
\hline $1.32 W$ & 19.40 & 0.301 & 27.36 & 0.2035 & 0.018 & 7.67 & 2.6 & $1639 \pm 3$ \\
\hline $1.38 \mathrm{~W}$ & 19.46 & 0.301 & 27.64 & $0.1995^{\circ}$ & 0.017 & 19.4 & 6.5 & $1642 \pm 3$ \\
\hline $1.44 W$ & 19.43 & 0.301 & 27.36 & 0.1972 & 0.018 & 21.0 & 7.1 & $1641 \pm 3$ \\
\hline $1.50 \mathrm{~W}$ & 19.84 & 0.304 & 27.53 & 0.2081 & 0.018 & 1750 & 57.9 & $1663 \pm 3$ \\
\hline $1.55 \mathrm{~W}$ & 19.47 & 0.301 & 26.78 & 0.2002 & 0.018 & 5.89 & 2.0 & $1642 \pm 3$ \\
\hline $1.60 \mathrm{~W}$ & 19.49 & 0.306 & 27.25 & 0.2016 & 0.018 & 2.66 & 0.9 & $1644 \pm 3$ \\
\hline $1.70 \mathrm{~W}$ & 19.68 & 0.310 & 27.40 & 0.2019 & 0.018 & 2.48 & 0.8 & $1655 \pm 3$ \\
\hline $1.90 \mathrm{~W}$ & 19.58 & 0.303 & 27.88 & 0.1994 & 0.017 & 3.93 & 1.3 & $1649 \pm 3$ \\
\hline $2.0 W$ & 19.53 & 0.301 & 27.37 & 0.1974 & 0.018 & 11.2 & 3.8 & $1646 \pm 3$ \\
\hline $2.3 W$ & 19.54 & 0.297 & 26.67 & 0.1974 & 0.018 & 5.37 & 1.8 & $1646 \pm 3$ \\
\hline $2.8 W$ & 19.69 & 0.298 & 27.68 & 0.1982 & 0.017 & 4.51 & 1.5 & $1655 \pm 3$ \\
\hline $3.3 W$ & 19.62 & 0.296 & 26.44 & 0.1929 & 0.018 & 2.44 & 0.8 & $1651 \pm 3$ \\
\hline $4.0 \mathrm{~W}$ & 20.32 & 0.294 & 27.97 & 0.2077 & 0.017 & 0.68 & 0.2 & $1689 \pm 7$ \\
\hline FUSE & 22.33 & 0.317 & 23.12 & 0.2239 & 0.021 & 0.82 & 0.2 & $1791 \pm 7$ \\
\hline
\end{tabular}

\footnotetext{
a Above $1200^{\circ} \mathrm{C}$ increments are labeled in watts of laser power. Ptaleau increments indicated by bold type.

b Corrected for ${ }^{37} \mathrm{Ar}$ decay (hall-life $=35.1$ days) and ${ }^{39} \mathrm{Ar}$ decay (hall-life $=269 \mathrm{yr}$ ).

c Decay constants: $\lambda_{E}=0.581 \times 10^{-10} \mathrm{yr}^{-1}, \lambda_{B}=4.692 \times 10^{-10} \mathrm{yr}^{-1}$. Errors assigned to individual ages in the age spectrum are estimates of the standard deviation of analytical precision and do not include the error in $J$, which is $0.5 \%$. The estimated error in the lotal fusion age for the glass includes the error in J. Ages calculated using the following correction factors: $\left({ }^{36} \mathrm{Ar} /{ }^{37} \mathrm{Ar}\right)_{\mathrm{Ca}}=0.000275 \pm 3,\left({ }^{38} \mathrm{Ar} /{ }^{37} \mathrm{Ar}\right)_{\mathrm{Ca}}=0.0000254 \pm 8,\left({ }^{39} \mathrm{Ar} /{ }^{37} \mathrm{Ar}\right)_{\mathrm{Ca}}=0.000675 \pm 7,\left({ }^{40} \mathrm{Ar} /{ }^{39} \mathrm{Ar}\right)_{\mathrm{K}}=0.00240$ $\pm 2,\left({ }^{38} \mathrm{Ar} / 39 \mathrm{Ar}\right)_{\mathrm{K}}=0.01067 \pm 4,\left({ }^{40} \mathrm{Ar} /{ }^{36} \mathrm{Ar}\right)_{\mathrm{Lr}}=1 \pm 1,\left({ }^{40} \mathrm{Ar} /{ }^{36} \mathrm{Ar}\right)_{\mathrm{Cos}}=0.018 \pm 6,\left({ }^{36} \mathrm{Ar} /{ }^{38} \mathrm{Ar}\right)_{\cos }=0.67 \pm 2$.
$\left({ }^{36} \mathrm{Ar}\right)_{\mathrm{LS}}=0.1869 \pm 17$.
}

abundance pattern is unique in its steepness of the HREEs (Fig. 4, 5), which even exceeds that of volcanic KREEP from either the Apollo 15 or 17 landing sites, and is most unlike high-Ti mare basalts (Figs. 4a,b, 5). Thus, the rare earth abundance pattern of 15434,28 cannot be produced from mixing known mare basalt compositions with KREEP, a mechanism that has been postulated for some of the Apollo 14 high-alumina basalts (Dickinson et al., 1985; Shervais et al., 1985a,b). The 15434,28 yellow glass is also distinct from the Apollo 15 yellow impact glass, whose rare earths mimic the pattern of KREEP (Figs. 4a,b, 5). Many other element pairs, e.g., $\mathrm{Al}_{2} \mathrm{O}_{3-}$ Eu (Fig. $6 c$ ), demonstrate that 15434,28 is not a mixture of any analyzed mare basalt type with KREEP. Other incompatible trace element ratios are not those of KREEP, e.g., Th (Fig. 6e) and $U$ are depleted relative to $\mathrm{Sm}$ (subchondritic), as they are in high-Ti basalts. Other mare basalt types tend to have a chondritic $\mathrm{Th} / \mathrm{Sm}$, and in contrast KREEP samples have a superchondritic $\mathrm{Th} / \mathrm{Sm}$.
Strontium (Fig. 6d) and Eu (Fig. 6c) abundances are in the range of high-Ti mare hasalts and KREEP, except for the Apollo 17 KREEPy basalt, which has low Sr. Thus, compared with other incompatible elements in KREEP, they are enriched (for Eu this can be seen in the deeper Eu anomaly of KREEP in Fig. 4a,b). Rubidium is higher than in mare basalts of any kind excepting Apollo 11 high-K high-Ti mare basalts.

The elevation in incompatible trace elements results in 15434,28 having a lower $\mathrm{Ti} / \mathrm{Sm}$ (about 1400 ) than most mare basalts, with the exception of some of the aluminous Apollo 14 and Luna 16 samples (Fig. 7). The analyses of these aluminous basalts were made on extremely small samples and the extreme values might not be representative; none of the group averages for Apollo 14 aluminous basalts have such low ratios (Dickinson et al., 1985; Shervais et al., 1985a,b). A Ti/Sm of less than 500 characterizes KREEP, the common component of lunar soils and breccias that has high abundances of incompatible trace elements (e.g., REEs more than 

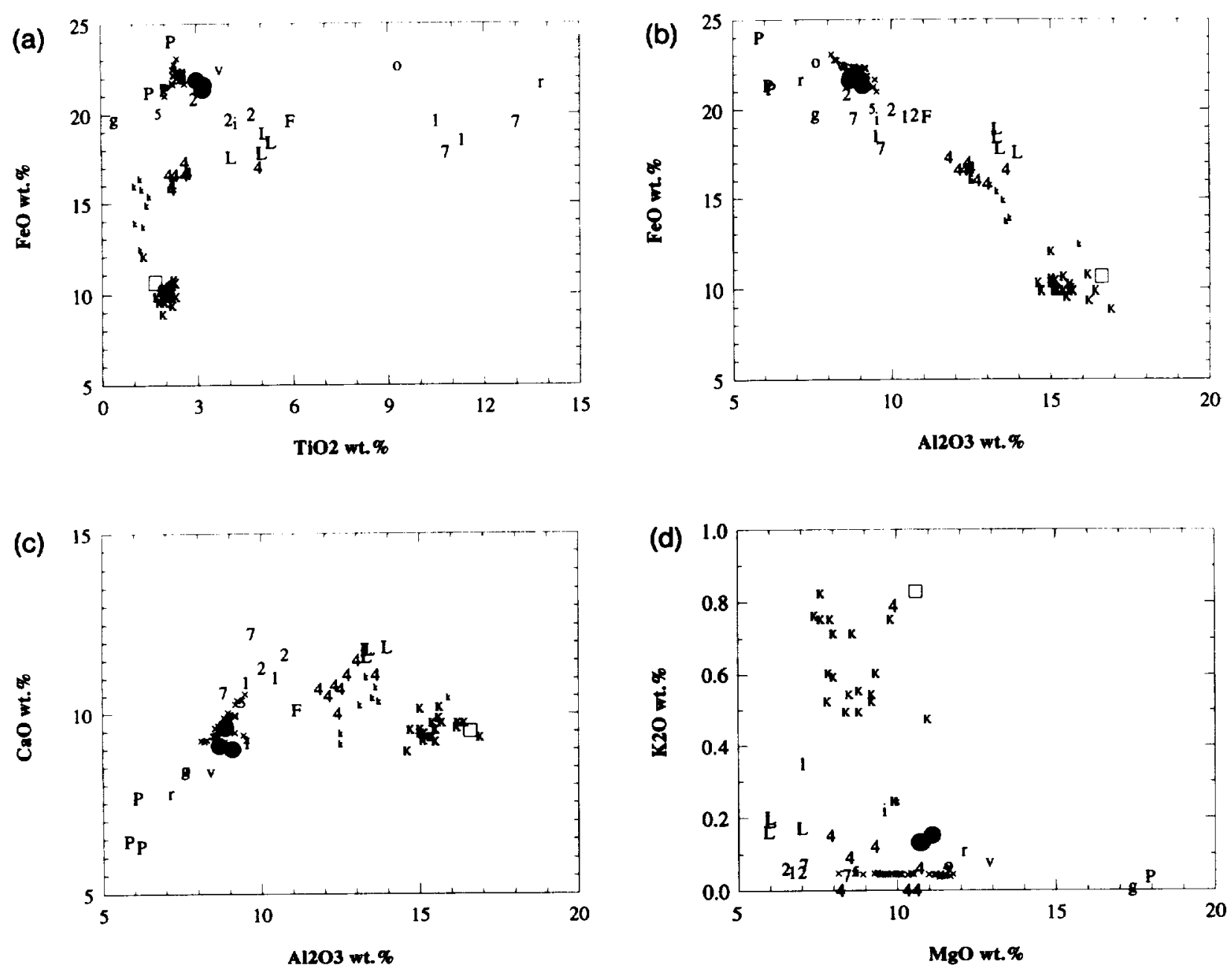

Fig. 3. Plots of major element data as oxide weight per cent of 15434,28,202 (from Table 2) and other lunar materials, mainy mare basalt types. (a) $\mathrm{FeO}$ vs. $\mathrm{TiO}_{2}$. (b) $\mathrm{FeO}$ vs. $\mathrm{Al}_{2} \mathrm{O}_{3}$. (c) $\mathrm{CaO}$ vs. $\mathrm{Al}_{2} \mathrm{O}_{3}$. (d) $\mathrm{K}_{2} \mathrm{O}$ vs. $\mathrm{MgO}$. Data taken mainly from Taylor et al. (1991). Key : Solid circles = Yellow glass 15434,28,202 (this study). $1=$ Apollo 11 high-Ti basalts. $2=$ Apollo 12 low-Ti basalts. $4=$ Apollo 14 high-alumina basalts $(5$ group averages plus very-high-potassium group) (Shervais et al., 1985a,b; Dickinson et al., 1985). $x=$ Apollo 15 olivine-normative basalts (Ryder and Schuraytz, unpublished). 5 = Apollo 15 quartz-normative basalts. $F=15388$ "feldspathic gabbro". $P=$ Apollo 15 "feldspathic peridotite". 7 = Apollo 17 high-Ti basalts. $\mathrm{i}=$ Apollo 15 yellow impact glass. $\mathrm{v}=$ Apollo 15 yellow volcanic glass. $r=$ Apollo 15 red (high-Ti) volcanic glass. $o=$ Apollo 17 orange volcanic glass. $K=$ Apollo 15 volcanic KREEP basalts (from data compiled in Ryder and Sherman, 1989). $\mathrm{k}=$ Apollo 17 volcanic KREEP (Salpas et al., 1987). Open square = typical high-K KREEP breccia.

$150 \times$ chondrites). It also characterizes many highlands $\mathrm{Mg}-$ suite igneous rocks such as norites (Norman and Ryder, 1980). The combination of major element composition and the non-KREEP-like incompatible element abundance pattern of 15434,28 (above) preclude simple contamination with common KREEP as an explanation of the Ti/Sm data.

The $\mathrm{Sc}, \mathrm{Ni}$, and $\mathrm{Co}$ abundances of 15434,28 are those of a low-Ti mare basalt (Fig. 6a,b,d). Among high-Ti basalts, only the Apollo 17 orange glass has such low Sc. The Sc/Sm of 15434,28 yellow glass is consequently very low (about 3 ; Fig. 7), far below chondritic (about 35 ). It is matched only by some rare Apollo 14 aluminous basalt fragments (Neal et al., 1988, 1989) and Luna 16 mare basalts, and by some Apollo 11 highTi high-K basalts (Basaltic Volcanism Study Project, 1981). Low $\mathrm{Sc} / \mathrm{Sm}$ is characteristic of KREEP and highlands $\mathrm{Mg}$ - suite rocks (Norman and Ryder, 1980) but such contamination with them is precluded by major and other trace element data as a cause of the low Sc/Sm of 15434,28. The low Sc (e.g., Fig. 6a) is extreme and precludes an origin by mixing of analyzed lunar materials; instead they suggest a unique mare origin for the 15434,28 glass.

15434,28 is not as enriched in incompatible element abundances as is the common Apollo 15 yellow impact glass (Fig. $4 a, b)$, whose incompatible element pattern is more KREEPlike (but also cannot contain a significant KREEP component; Delano et al., 1982). The common yellow impact glass has ratios of $\mathrm{Th}$ and $\mathrm{U}$ to other incompatible elements similar to those in KREEP (Fig. 6e), so mixing that impact glass with either the yellow volcanic glass or other low-Ti mare basalts cannot produce incompatible element ratios like those of 

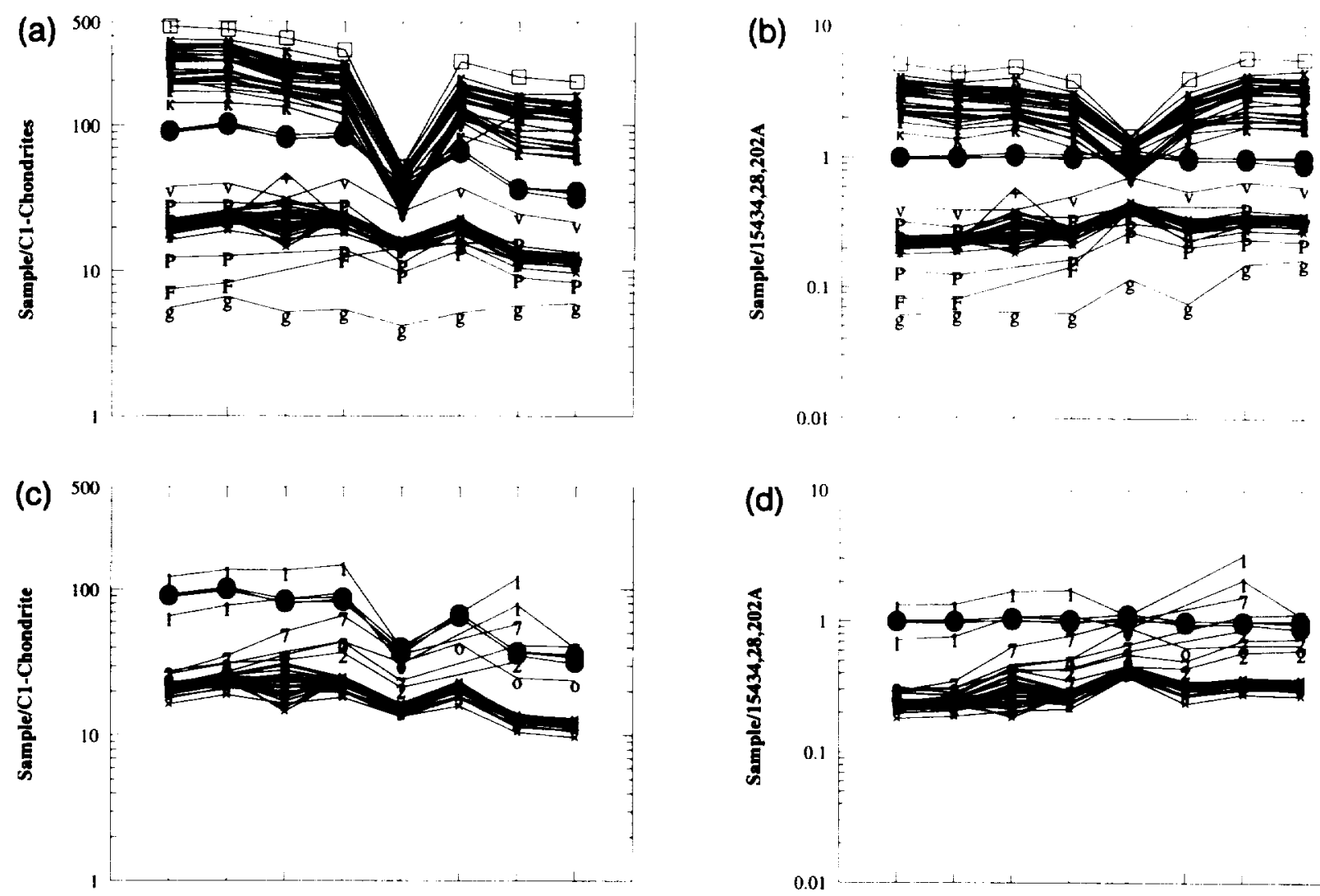

(d) 10
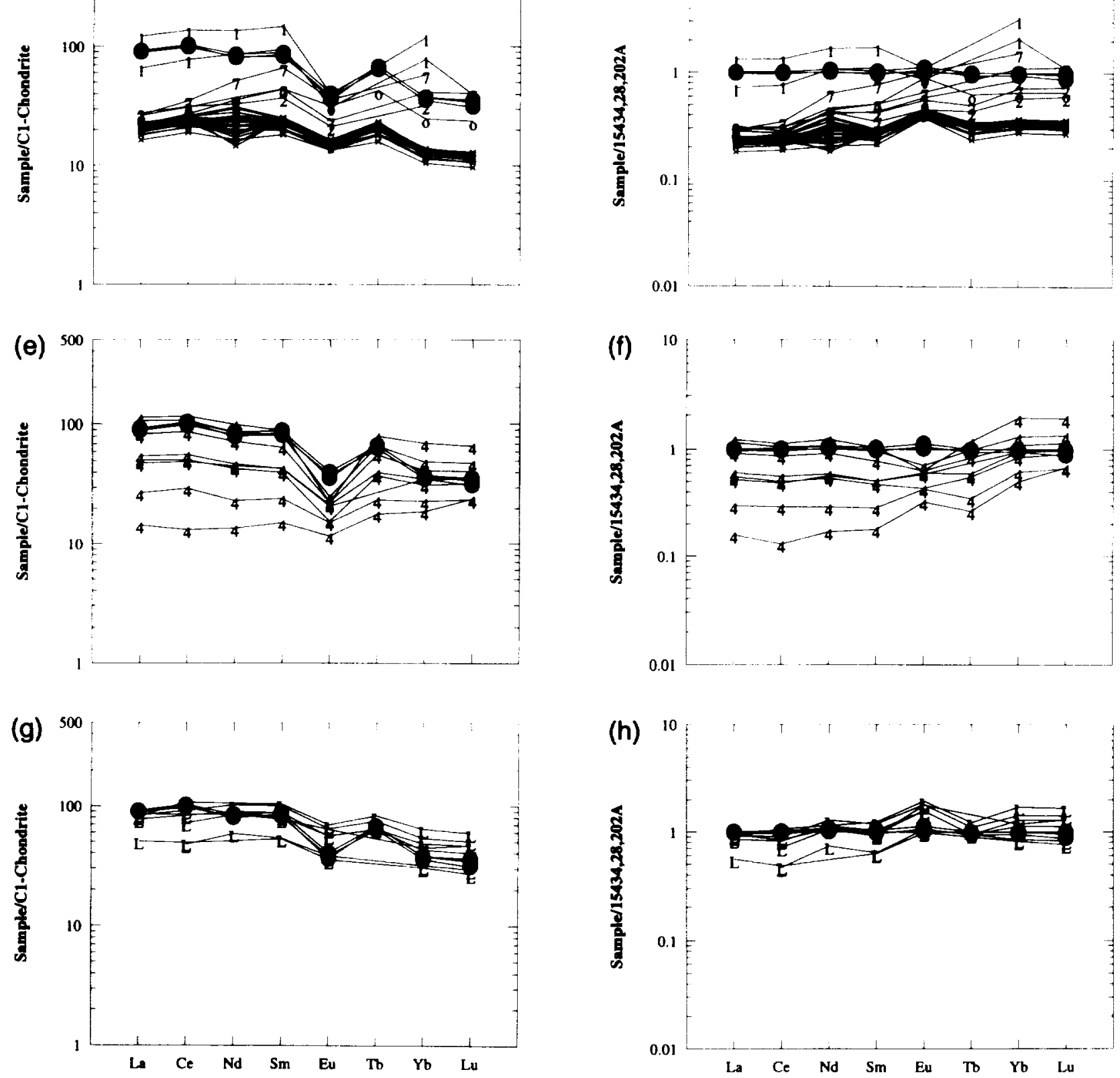
15434,28 . The major and trace element abundances (Figs. 37) thus demonstrate that the 15434,28 glass is not a mixture of components known to exist within the Apollo 15 landing site.

\subsection{Trace Volatile and Siderophile Elements}

The analyses of the interior glass of 15434,28 by synchrotron $\mathrm{X}$-ray fluorescence and radiochemical neutron activation (Table 2) show that the glass has low abundances of the volatile element $\mathrm{Zn}$ (less than or equal to about $1 \mathrm{ppm}$ ), similar to that in crystalline mare basalts and impact glasses, but much lower than the interiors of volcanic glasses (more than $30 \mathrm{ppm} \mathrm{Zn;} \mathrm{Delano} \mathrm{et} \mathrm{al.,} \mathrm{1991).} \mathrm{The} \mathrm{Zn} \mathrm{data} \mathrm{suggest} \mathrm{that} \mathrm{the}$ glass was produced by impact into a crystalline mare basalt source. (If a volcanic glass target is assumed instead then one can invoke volatilization loss of $\mathrm{Zn}$, although other elements such as $K$ and $R b$ suggest that volatile loss could not have been extensive).

The analyses of the glass by radiochemical neutron activation show that it is slightly enriched over indigeous lunar abundances in meteoritic siderophiles such as Ir (Table 2; Fig. 8). The abundances exceed the arbitrary "cut-off" for pristinity of lunar rocks (Haskin and Warren, 1991) by factors up to about 4 , but reflect only about 0.05 wt $\% \mathrm{Cl}$-carbonaeous chondrite (volatile-free) of contamination. Although $\mathrm{Ni}$ is greatly above the pristinity cut-off, most of the $\mathrm{Ni}$ is likely to be of indigenous origin in such a mare composition; indeed, the Ni abundance is typical for crystalline mare basalts most similar in major element composition. The subsample that includes rind is slightly more enriched than the pure glass in all siderophile elements but $\mathrm{Ni}$ (e.g., Ir $0.62 \mathrm{ppb}$ cf. $0.44 \mathrm{ppb}$ ). The relative abundances of meteoritic elements are not those of typical polymict material or chondritic meteorites (e.g., Ge/ Ir is only $0.1 \times$ that of $\mathrm{Cl}$-type carbonaceous chondrites), and possibly the data require an explanation combining low-level meteoritic contamination with loss of meteoritic volatiles. If the siderophile element abundances do include components of meteoritic contamination, then contamination is less than in nearly all polymict materials, and much less than in typical regoliths developed on mare flows. Even extremely immature soil 15530 from the edge of Hadley Rille contains more than 3 ppb Ir (Baedecker et al., 1973). If the 15434,28 glass was produced in an impact, neither the impactor nor the target contributed more than a smattering of meteoritic contamination to the melt.

\section{AGE OF INTERIOR GLASS}

The ${ }^{411} \mathrm{Ar} /{ }^{39} \mathrm{Ar}$ age spectrum, consisting of thirty increments (Table 3), is essentially flat over $96 \%$ of the ${ }^{39} \mathrm{Ar}$ released even though over half of the ${ }^{31} \mathrm{Ar}$ was released in a single increment (Fig. 9). The seventeen plateau increments indicate a weighted mean age of $1647 \pm 11 \mathrm{Ma}(2 \sigma)$, which we in-

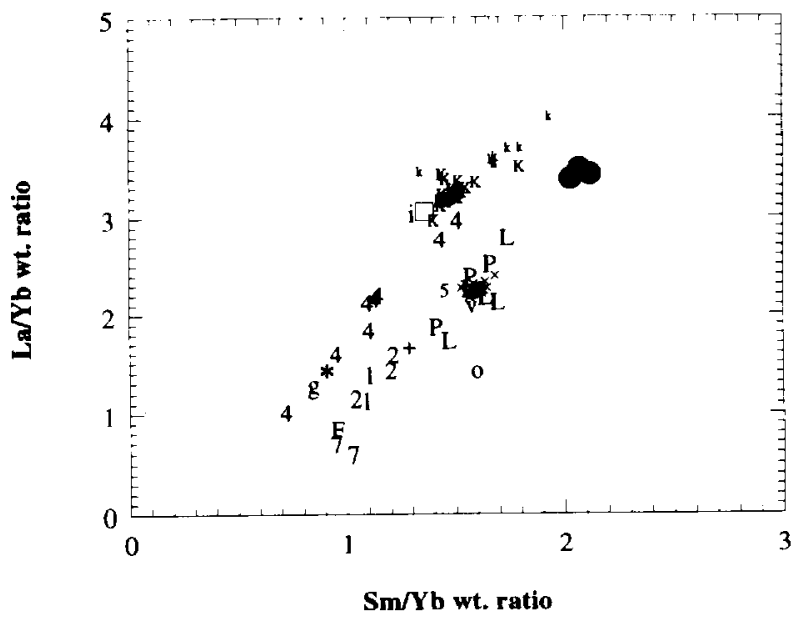

FIci. 5. La/Yb vs. Sm/Yb for 15434,28,202 and other lunar samples. Data sources and key as in Fig. 3. Asterisk is location of chondritic $\mathrm{La} / \mathrm{Yb}$ and $\mathrm{Sm} / \mathrm{Yb}$ (and by necessity, chondritic $\mathrm{La} / \mathrm{Sm}$ ). On this diagram, two-component mixing lines would be straight.

tepret as the cooling age of the glass. The lack of trapped argon (see section 10) is consistent with total degassing of argon from the melt and its rapid solidification at $1647 \mathrm{Ma}$. Most of the thirteen nonplateau increments are very small and, as a consequence, have large errors and may even be fractionated; no additional age or thermal history information can be inferred from them. The $\mathrm{K} / \mathrm{Ca}$ spectrum, calculated from the corrected ${ }^{37} \mathrm{Ar} /{ }^{39} \mathrm{Ar}$ ratios, is constant over the entire release, consistent with the release of argon isotopes generated by fast-neutron reactions with calcium and potassium in a homogeneous glass.

The relatively young cooling age of $1647 \pm 11$ Ma for the glass is more consistent with an impact origin, because lunar volcanism younger than 2 Ga must be very rare, according to photogeological interpretations. Nonetheless, the age does not independently preclude a volcanic origin. The glass is much younger than both the Apollo 15 yellow volcanic glass ( 3620 $\pm 70 \mathrm{Ma}$; Spangler et al., 1984) and the common Apollo 15 impact glass ( $3350 \pm 50 \mathrm{Ma}$; Spangler and Delano, 1984). The age of 1647 Ma places the glass formation in Copernican time (less than about $2.2 \mathrm{Ga}$; Ryder et al., 1991) or late Eratosthenian (if Copernican starts at about $1.2 \mathrm{Ga}$; Wilhelms, 1987). Thus, the formation of the glass postdated any known volcanism in the Imbrium region.

\section{RIND INCLUSIONS}

The rind consists of quenched or devitrified glass and inclusions of mineral and lithic fragments. It contains some FeNil sulfide blebs; Fe-metal appears to be absent. The inclusions consist entirely of minerals and lithic fragments of mare derivation, and a few small brown devitrified glass spherules

Fici, 4. Rare earth elements in 15434,28,202 and other lunar samples. Data sources and key as in Fig. 3. In the lefthand side, data are normalized to $\mathrm{Cl}$ chondrite abundances, all to same axis scale. In the right-hand side, data are normalized to $15434,28,202 \mathrm{a}$, all to same axis scale, (a.b) Apollo 15 mare basalts, KREEP, volcanic glasses, and impact yellow glass. (c,d) Typical high-Ti and low-Ti mare basalts and volcanic orange glass. (e,f) Aluminous Apollo 14 mare basalts. (g,h) Aluminous Luna 16 basalts. 

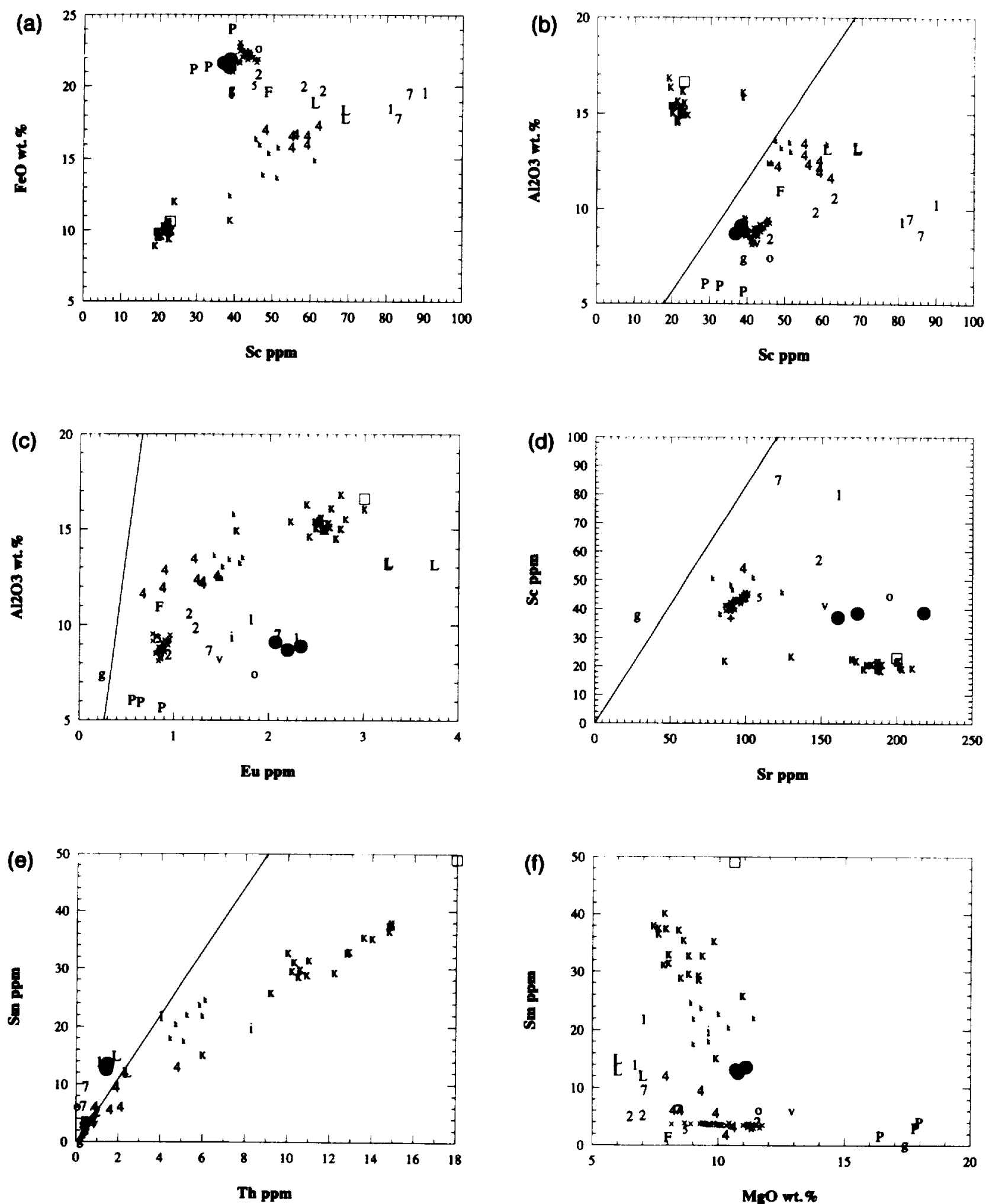

Fici. 6. Element-element plots for 15434,28,202 and other lunar samples. (a) $\mathrm{FeO}$ vs. Sc. (b) $\mathrm{Al}_{2} \mathrm{O}$, vs. $\mathrm{Sc}$. (c) $\mathrm{Al}_{2} \mathrm{O}$, vs. Eu. (d) Sc vs. Sr. (e) $\mathrm{Sm}$ vs. Th. (f) $\mathrm{Sm}$ vs. MgO. Data sources and key as in Fig. 3. Where plotted, straight lines are the chondritic ratios. 


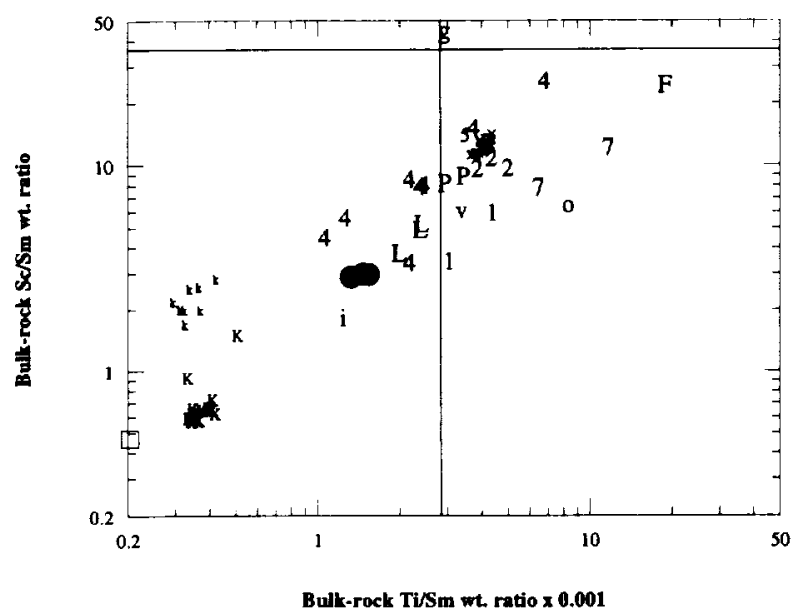

FIG. 7. Sc/Sm vs. Ti/Sm for $15434,28,202$ and other lunar samples. Data sources and key as in Fig. 3. Straight lines are the chondritic ratios.

of Apollo 15 volcanic green glass composition. Olivines, pyroxenes, and plagioclases are dominant, with lesser ulvospinel/ilmenite and chromite. The mineral and lithic fragments are subangular and have not noticeably reacted with the melt; the devitrified spherules are perfectly round. Shock deformation lamellae and maskelynite are absent. Microprobe analyses show that the mineral phases are typical of low-Ti mare basalts, more precisely typical of the Apollo 15 olivine-normative mare basalts.

The olivine fragments are zoned and have a compositional range from 0 to $65 \mathrm{~mol} \%$ Fo, with the high $\mathrm{CaO}$ abundances (about $0.3 \mathrm{wt} \%$ ) characteristic of mare basalt olivines (Fig. 10a). While the $\mathrm{CaO}$ contents do not discriminate well among mare basalts, $\mathrm{TiO}_{2}$ contents of olivine fragments are similar to those in Apollo 15 olivine-normative mare basalts, but unlike those in many other mare basalt types such as Apollo 17 high-Ti basalts and some Apollo 12 basalts (Fig. 10b). The pyroxene fragments are also zoned with a wide range of compositions (Fig. 11), most similar to those of the local Apollo 15 olivine-normative basalts (Fig. 11a). Apollo 15 quartz-normative mare basalts have common $\mathrm{Mg}$-pigeonites that are not represented among these inclusions. The minor element abundances in the pyroxenes allow greater discrimination than the major elements alone; $\mathrm{Al}_{2} \mathrm{O}_{3}$ contents ( $\mathrm{Fig}, 12$ ) in particular are like those of Apollo 15 olivine-normative mare basalts (Fig. 12a); some Apollo 15 quartz-normative basalts contain
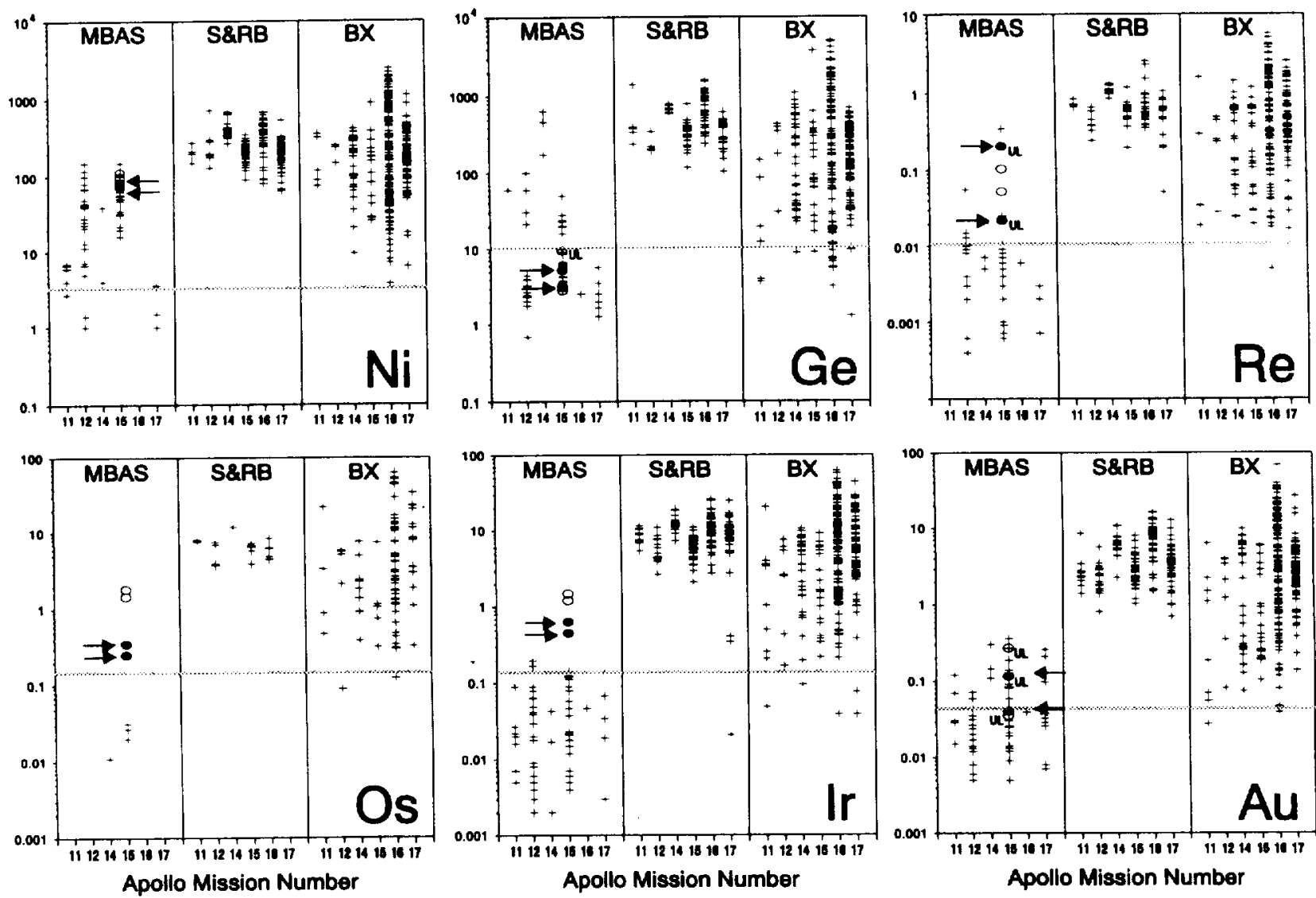

Ftci. 8. Abundances of siderophile elements Ni, Ge, Re, Os, Ir, and Au in 15434,28,202 F and G (filled ellipses, indicated by arrows) and other relevant lunar samples. The unfilled ellipses are the 15010 yellow impact glass (Ebihara et al.. 1992). UL $=$ upper limit. MBAS $=$ Mare basalts. $S \& R B=$ Soils and regolith breccias. $\mathbf{B X}=$ Polymict breccias. See Haskin and Warren (1991) for data sources. Concentrations are in ng/g (parts per billion) except Ni $\mu \mathrm{g} / \mathrm{g}$ (parts per million). Horizontal lines indicate $3 \times 10^{+}$times $\mathrm{C} 1$ chondrites, commonly used as a reference for distinguishing pristine from meteorite-contaminated lunar samples. 

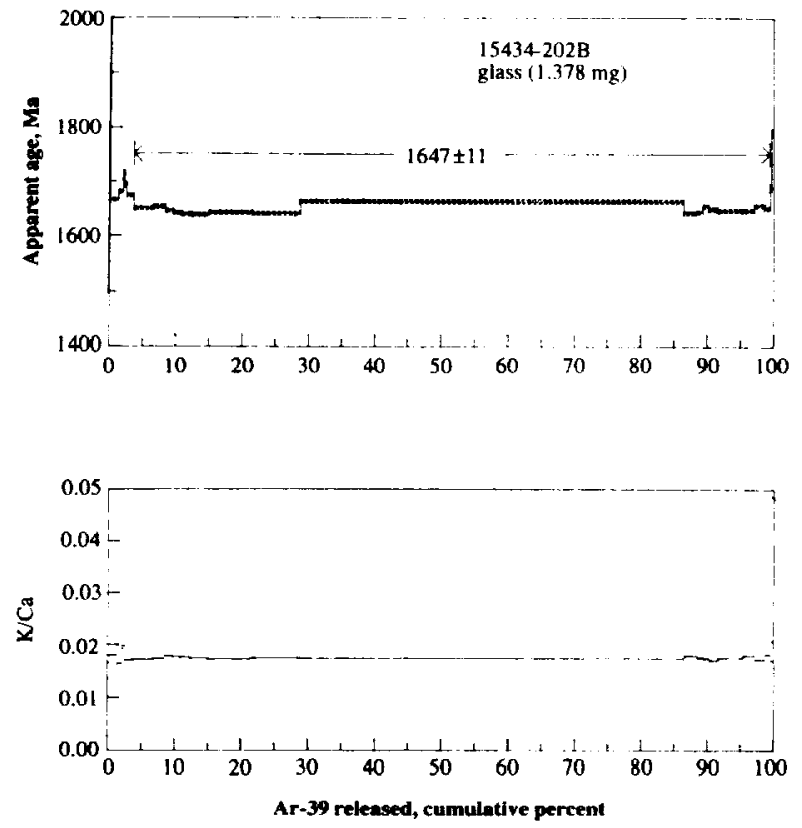

FIG. 9. "Ar/"Ar age spectrum (top) and $\mathrm{K} / \mathrm{Ca}$ ratio (bottom) of 15434.28,202B glass measured by laser step heating. Half of the vertical dimension of the increment boxes is the estimated standard deviation of the precision of the increment age. The error in the weighted mean plateau age is twice the standard error $(95 \%$ confidence level)

pyroxenes that are zoned to high alumina contents (Fig. 12b). Pyroxenes in high-Ti basalts generally have rather higher alumina (and titania) (Fig. 12c). However, other low-Ti mare basalts, such as those from Apollo 12, have pyroxenes not unlike those in $15434,28,130$ in alumina content (Fig. 12c). Nonetheless, the combination of major and minor elements for the pyroxene inclusions is most consistent with a source in Apollo 15 olivine-normative basalts. The plagioclase inclusions are easily distinguished from plagioclases from KREEP, from ferroan anorthosite, or from highlands magnesian suite rocks on the basis of $\mathrm{FeO}$ and $\mathrm{MgO}$ contents (Fig. 13), and fall in the range of plagioclases in mare basalts. However, the compositions do not allow a particular mare source to be identified, although both high- $\mathrm{Ti}$ and very low-Ti mare basalt sources appear to be ruled out. The ulvospinel/ilmenite grains also have compositions (e.g., low $\mathrm{MgO}$ in ilmenite) consistent with a mare origin. None of the mineral inclusion data is inconsistent with an Apollo 15 olivine-normative mare basalt source.

Four small devitrified spherules were analyzed using the microprobe, and are of Apollo 15 volcanic green glass composition. On the basis of $\mathrm{Mg} / \mathrm{Si}, \mathrm{Al} / \mathrm{Mg}, \mathrm{Mg} / \mathrm{Fe}$, and $\mathrm{CaO}$ abundances, two belong to Group A and two belong to Group $\mathrm{D}$, the two most common groupings among Apollo 15 volcanic green glasses (Delano, 1979; Ryder, 1986).

The rind inclusions are apparently derived principally from a slowly cooled Apollo 15 olivine-normative mare basalt, with a very minor component of volcanic green glass. The conspicuous presence of olivine and lack of pyroxene either with the morphology of phenocrysts (e.g.. laths in fine-grained groundmass) or with the low-Ca pigeonite composition com- mon in the Apollo 15 quartz-normative basalts suggest that the olivine basalt is virtually unaccompanied by other basalt types. No KREEP hasalt or feldspathic crustal debris is present, nor is yellow volcanic or impact glass.

The sharp contrast between the homogeneous, crystal-free glass itself and the coarse mare fragments in the rind suggest that there was no close igneous relationship of the glass and the inclusions. The pyroxenes probably contain insufficient titania to he related to the glass. The glass is much younger than the mineral fragments (1647 Ma, cf. $3350 \mathrm{Ma}$, assuming that they are from the local basalts), which could thus only be related by contributing 10 the melt in the parental impact. The inclusions in the rind must have been picked up during flight, while the melt was completely liquid. If they had been picked up at the instant of melt production, they would have been
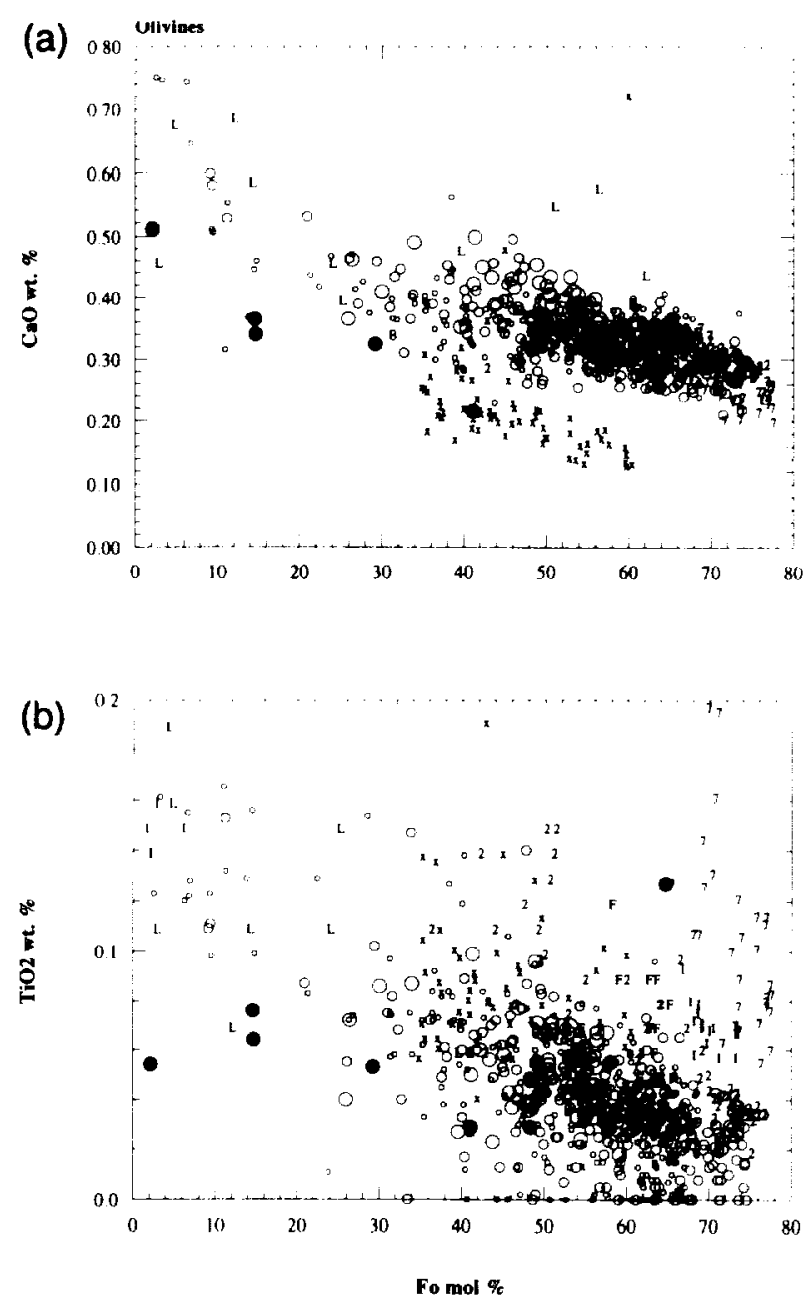

FIG. 10. Compositions of olivines in rind of $15434,28,130$ and in some lunar mare basalts. (a) $\mathrm{CaO}$ wt\% vs. Fo mol\%. (b) $\mathrm{TiO}$. vs. Fo mol\%. Filled circles $=15434,28,130$. Open circles = Apollo 15 olivine normative basalts (large,coarser-grained; small, finer-grained) (G. Ryder and Schuraytz, unpubl. data). 7 = high-Ti basalt in 79001 (Ryder $1990 \mathrm{c}$ and unpubl. data). $X=$ Apollo 15 vitrophyre 15474,4 (Ryder and Burling, 1996). 2 = Apollo 12 olivine basalts (Busche et al., 1971; Butler, 1972) I = Apollo 12 ilmenite basalts (Busche et al., 1971; Butler. 1972) $\mathrm{F}=$ Apollo I5 feldspathic gabbros and peridotites $\left(\mathrm{TiO}_{2}\right.$ data only, from Dowty et al., 1973). $\mathrm{L}=$ Luna 24 very low-Ti mare basalts (various sources). 


\section{Pyroxenes}

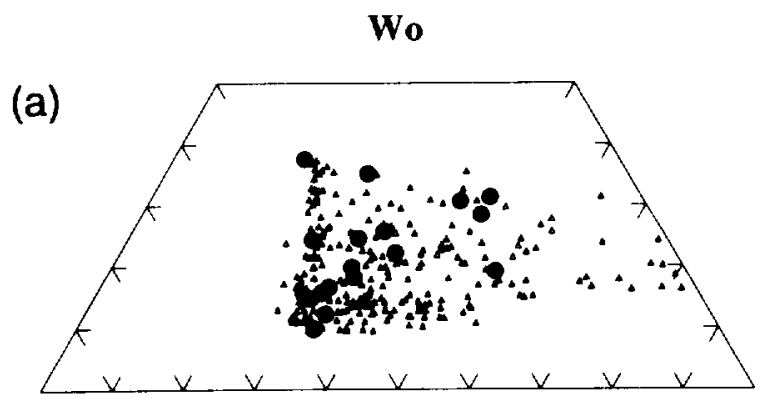

En

Fs

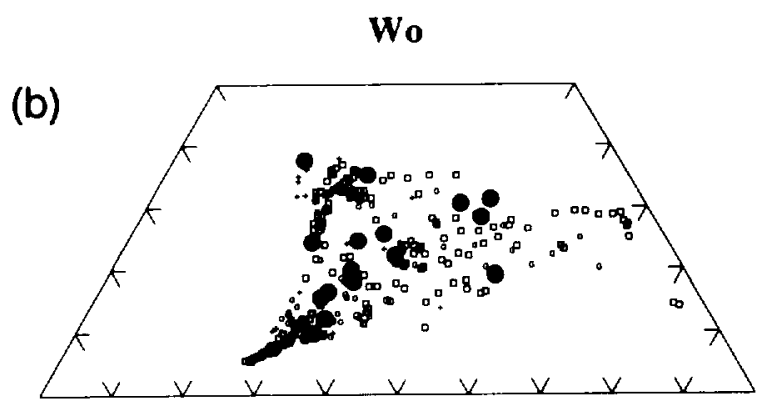

En

Fs

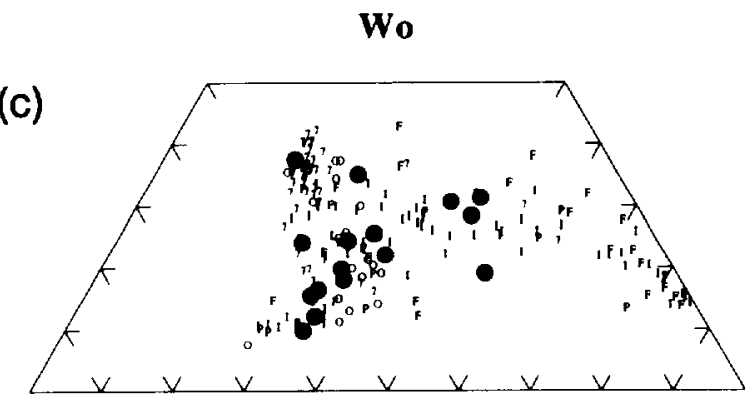

En

Fs

Fici. 11. Quadrilateral components (based on $\mathrm{Mg}-\mathrm{Fe}-\mathrm{Ca}$ ) of pyroxene fragments in rind of $15434,28,130$ and in some mare basalts. In all diagrams 15434,28,130 fragments are the solid circles. (a) Apollo 15 olivine-normative mare basalts (Dowty et al., 1973). (b) Other Apollo 15 mare basalts. Squares = Apollo 15 quartz-normative basalts. $G=$ "feldspathic microgabbro" 15388. $+=$ "feldspathic peridotite" 15385 and 15387. (Dowty et al., 1973). (c) Apollo 12 and Apollo 17 basalts. $\mathrm{O}=$ Apollo 12 olivine basalts. $\mathrm{P}=$ Apollo 12 pigeonite basalts. $\mathrm{F}=$ Apollo 12 feldspathic basalt. $\mathbf{I}=$ Apollo 12 ilmenite basalt. (Dowty et al., 1973). $7=$ High-Ti mare basalt in 79001 (Ryder. 1990c, and unpubl. data).

more evenly distributed through the melt. The glass had already solidified, with the inclusions in its rim, at the time of landing. If the inclusions had been attached after landing, the glass would surely not have retained its spherical shape if it was soft enough for crystals to sink into it. The rim material however is consistently slightly higher in siderophile element abundances than is the interior. This is consistent with the exterior materials containing a minor regolith component, either in flight from an expanding cloud of the target area, or as a thin adhering dust coat on or after landing.

\section{PRODUCTION OF THE GLASS AND RIND}

The 15434,28 interior glass is homogeneous and the melt was completely outgassed of argon; thus, it was probably held
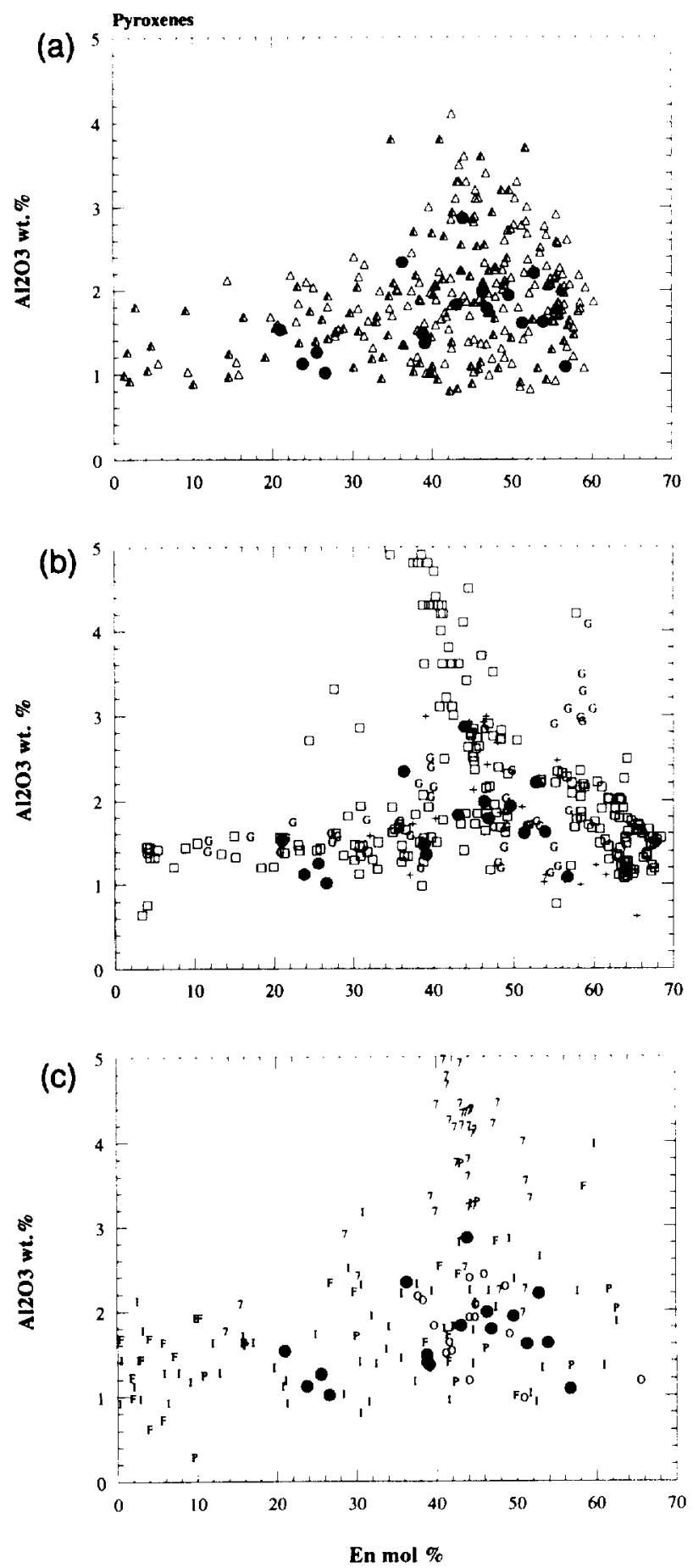

Fici. 12. $\mathrm{Al}_{2} \mathrm{O}_{3}$ vs. En mol\% in pyroxene fragments in the rind of 15434.28.130, and in some mare basalts. Key as in Fig. 11. 

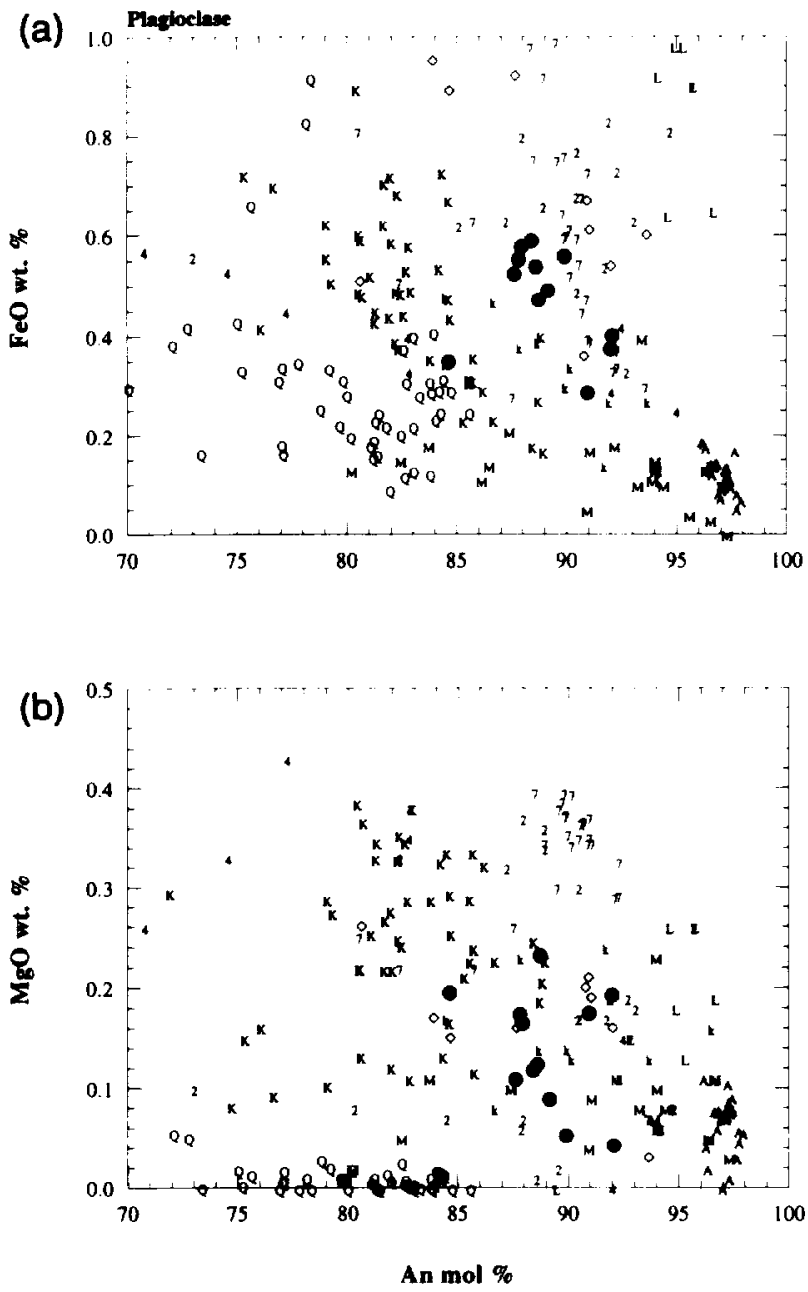

Fig. 13. Compositions of plagioclases in rind of $15434,28,130$ and in other lunar rock types. (a) $\mathrm{FeO}$ wt\% vs. An mol\%. (b) $\mathrm{MgO}$ vs. An mol\%. Solid circles $=15434,28,130$ rind. $Q=$ quartz-monzodiorite. $\mathbf{K}=$ Apollo 15 volcanic KREEP basalts. (G. Ryder, unpubl. data). $\mathrm{A}=$ ferroan anorthosites (mainly McGee, 1993). $\mathbf{M}=$ highlands magnesian suite. $7=$ high-Ti mare basalt from Apollos 11 and 17. 2 = Apollo 12 mare basalts. diamond $=$ Luna 16 mare basalts. $\mathrm{L}=$ Luna 24 very-low Ti mare basalts. $4=$ Apollo 14 aluminous mare basalts. (Papike et al., 1991, and other sources).

above the liquidus for at least several seconds. The spheruleshape demonstrates that the melt cooled while in a ballistic trajectory, solidified sufficiently during flight to retain its shape on landing, and lost sufficient surface heat that regolith

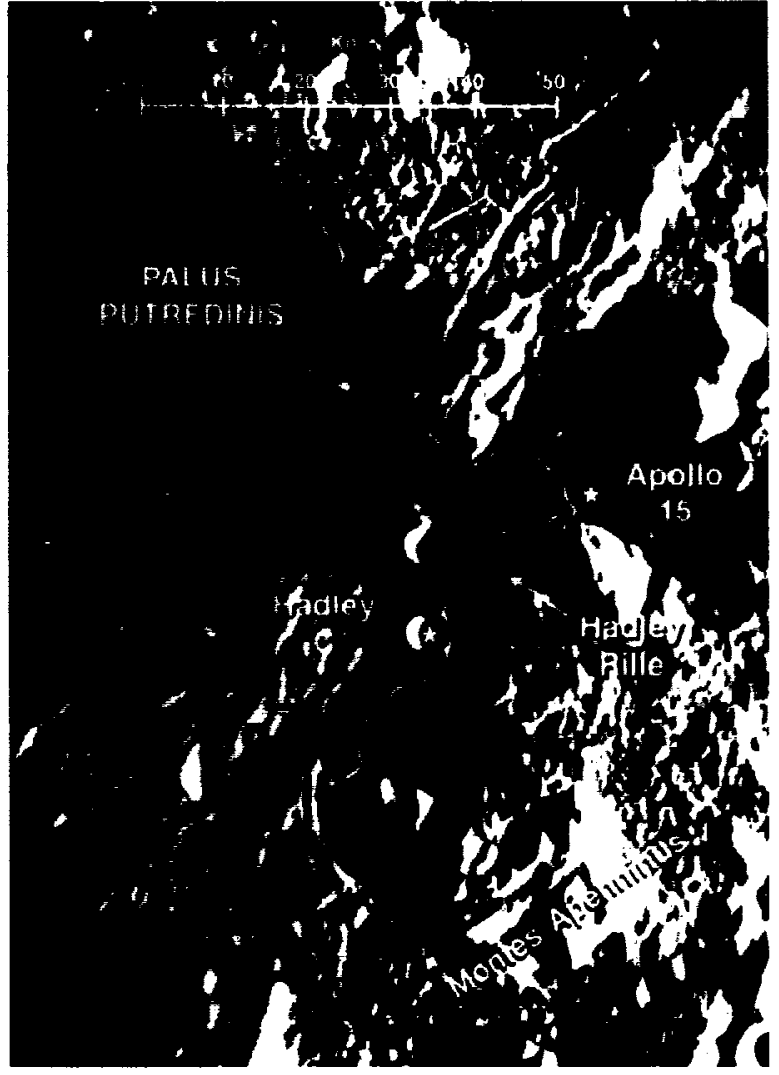

FiG. 14. Orbital photograph showing the Apollo 15 landing site and Hadley C (part of Apollo 15 Frame M-414). Sinuous rille is Hadley Rille, on which Hadley C is superimposed about $30 \mathrm{~km}$ southwest of the landing site. No other large craters into mare plains of Palus Putredinis occur so close to the collection spot of 15434,28. Arrow points to two craters in mare terrain that are also candidates for the source of 15434,28. Apart from the mare, much of the terrain within $100 \mathrm{~km}$ of the Apollo 15 site is occupied by the Apennine Bench Formation (lower left) that is the manifestation of volcanic KREEP basalts, and by Montes Apenninus that is composed of noritic breccias.

dust did not strongly adhere to it on landing. Cooling of the rind appears to have been effected by the addition of inclusions to the exterior, insofar as they provided the nucleation sites for crystallization or devitrification or both. These observations can be used to place a lower limit on the travel time of the spherule.

Properties calculated for the melt/glass composition of 15434.28 are listed in Table 4. The liquidus temperature for

TABLE 4. List of calculated poperties for 15434,28 composition

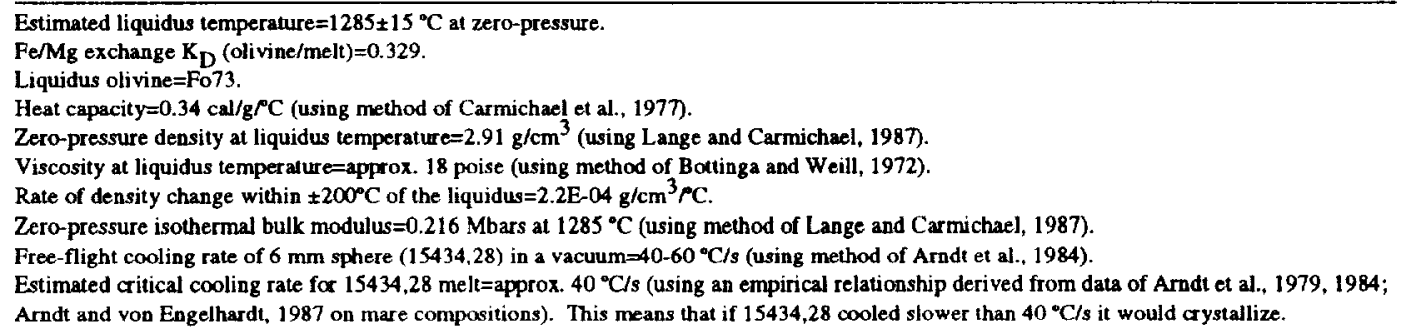


TABLE 5. Cosmic ray exposure (CRE) ages for 15434,28 glass (subsample ,202) for various shielding depths. The production rate of ${ }^{38} \mathrm{Ar}$ from $\mathrm{Ca}\left(\mathrm{P}^{38} \mathrm{Ca}\right)$ is given to facilitate comparison of these CRE ages with those for other lunar samples. which cormmoniy do not include the contributions of $\mathrm{Fe}, \mathrm{Ti}$, and $\mathrm{K}$.

\begin{tabular}{cccc}
\hline $\begin{array}{c}\text { Shielding Depth } \\
\left(\mathrm{g} / \mathrm{cm}^{2}\right)\end{array}$ & $\begin{array}{c}\mathrm{P}^{38}[\mathrm{Ca}] \\
\text { (ccSTP/gCa-Ma) }\end{array}$ & $\begin{array}{c}\text { CRE Age } \\
(\mathrm{Ma})\end{array}$ & $\begin{array}{c}\text { Target Contributions } \\
\text { (Ca:Fe:Ti:K) }\end{array}$ \\
\hline 0 & $5.53 \times 10^{-8}$ & 144 & $94.6: 1.3: 0.9: 3.1$ \\
1 & 2.29 & 342 & $93.3: 3.1: 1.9: 1.7$ \\
5 & 1.07 & 700 & $89.2: 6.1: 3.2: 1.5$ \\
65 & 1.14 & 678 & $92.5: 3.6: 2.3: 1.6$ \\
100 & 1.03 & 762 & $93.4: 3.0: 2.0: 1.6$ \\
150 & 0.860 & 920 & $94.3: 2.3: 1.7: 1.6$ \\
225 & 0.651 & 1229 & $95.3: 1.7: 1.4: 1.6$ \\
500 & 0.120 & 6753 & $96.4: 0.9: 1.0: 1.7$
\end{tabular}

a glass of the 15434,28 composition is a little under $1300^{\circ} \mathrm{C}$. Free-flight cooling rates for a sphere of this size and composition in a vacuum are about 40 to $60^{\circ} \mathrm{C} \mathrm{s}$ ', dropping to about $20^{\circ} \mathrm{C} \mathrm{s}{ }^{\prime}$ at temperatures around $800^{\circ} \mathrm{C}$ (below which regolith adhesion might not occur). The critical cooling rate for this composition (i.e., to avoid crystallization) through 1300 to $1000^{\circ} \mathrm{C}$ is similarly about $40^{\circ} \mathrm{C} \mathrm{s}{ }^{1}$, and then faster than about $20^{\circ} \mathrm{C} \mathrm{s}{ }^{\prime}$ through about $800^{\circ} \mathrm{C}$. Thus the glass must have come very close to crystallizing (as is indeed suggested by the rind).

Lunar volcanic melt droplets were enveloped in a hot gas phase that might have significantly slowed the cooling rates, or radiation shielding within a dense cloud of droplets might have retarded cooling (Arndt et al., 1979, 1984). For instance, although the critical cooling rate for the Apollo 15 green glass is about $1^{\circ} \mathrm{C} \mathrm{s}^{11}$, many of the green glasses in the 200 to 400 $\mu \mathrm{m}$ size range are partly crystalline, presumably due to the presence of a hot plume of gas or to radiation shielding that slowed the cooling rates. The lack of crystallization for the interior of 15434,28 may indicate that the glass formed in an impact, because an impact vapor plume might be expected to dissipate more rapidly (as a single rather than a continuous prolonged event), and because the larger droplet sizes and thinner clouds of impact products would provide less radiation shielding . The minimum time required for melt homogenization, and solidification to a nonplastic silicate solid (from superliquidus to about $700^{\circ} \mathrm{C}$ ) is of the order of 10 to $15 \mathrm{~s}$ for the 15434,28 composition, requiring that the melt spherule was in free flight over a minimum distance of several kilometers. The flight path might have been vertical.

We tentatively infer that the glass spherule was produced in an impact $1647 \pm 11 \mathrm{Ma}$ ago. Nonetheless, the pure glass interior and the rind with inclusions are unusual features of an impact melt. They appear to require that a spherule of sticky melt passed through a cooler, slower moving part of the ejecta. Inclusion of fragments caused more rapid cooling of the rim, but also provided nucleation sites that promoted crystallization. Thus, solidification of the outer rind reinforced the spherical shape. The interior melt must have continued to cool rapidly by conduction through the rind, resulting in a homogeneous interior glass.

\section{SOURCE TERRAIN FOR THE IMPACT: ROCK TYPES}

Spherule 15434,28 is probably of impact origin, according to the slight enrichment of meteoritic siderophiles and volatiles and its young age, although such an inference is questionable. It is nonetheless physically and chemically quite dis- tinct from most impact glasses, leading Ryder (1990a,b) to prefer the interpretation of a volcanic origin. Typical mature regolith contains about $1.5 \mathrm{wt} \%$ of meteoritic material, so could contribute less than $2 \mathrm{wt} \%$ of any mixture that went into the melt; it could not even have been $2 w t \%$ if there were any contribution from the impactor itself.

The high iron, low alumina, and non-KREEP-like incompatible element abundances are most consistent with a mare source, with negligible or no inclusion of KREEP or highlands materials. An impact melt could represent either a single mare flow or a mixture of more than one. Either way, the source terrain included at least one dominant basalt that is quite distinct from any other analyzed mare basalt type. If we assume a single mare type (and there appears to be no compelling reason to believe otherwise), then it has the unusual chemical features described above, i.e., the major and transition metal abundances of a low-Ti mare basalt, and the Sr and incompatible element abundances of a high-Ti mare basalt.

If we assume that the glass is a mixture, a simple mix of typical high-Ti and low-Ti basalts will not satisfy the chemical constraints, e.g., the low Ti/Sm and Sc/Sm (Fig. 4). On many simple plots of chemical composition, some mix of about equal proportions of Apollo 15 olivine normative basalt and Apollo 15 yellow volcanic glass, on the one hand, and common Apollo 15 yellow impact glass, on the other hand, satisfies much of the data (Fig. 5). However, the yellow impact glass, which has high $U$ and $T h$, raises ratios of $U$ and Th to $\mathrm{TiO}_{2}$ and other incompatible elements well above those of 15434,28 . Without further evidence, the exercise of computing possible mixture components in detail seems fruitless.

Delano et al. (1982) concluded that the common, older, Apollo 15 yellow impact glass was also from an impact into a distinct and unsampled mare basalt type. That terrain had higher incompatible element abundances than the target or source for 15434,28 , and ratios of $U$ and $T h$ to the other incompatible elements that are typical of KREEP and more like other low-Ti mare basalts.

\section{SOURCE TERRAIN FOR THE IMPACT: LOCATION}

Although the basalt or pile of basalts that we infer for the source terrain of 15434,28 is unlike other analyzed mare flows, it would not be distinctive from them in current remote and orbital geochemical datasets; it would appear as a typical low-Ti mare basalt. Many basalts in the Imbrium region have appropriate titanium abundances within the precision of the remote or orbital data (e.g., Whitford-Stark and Head 1980).

The age of the source terrain basalts can be defined only as older than $1647 \pm 11 \mathrm{Ma}$. The possibility exists that this unusual mare terrain is thus geologically young, as is no longer tenable for the common yellow impact glass (Spangler and Delano 1984). Presumably the basalt was at or near the surface at $1647 \mathrm{Ma}$, not deeply buried beneath other flows. If the inclusions were incorporated in flight, they must have been thrown up in the impact that formed the 15434,28 melt. The inclusion of two types of local mare material (Apollo $15 \mathrm{ol}$ ivine-normative basalts and Apollo 15 green glass types A and D) suggests that the source terrain is also local. However, the source was not actually in the Apollo 15 landing area, or more samples of it would surely have been recognized. The 
source was probably within Palus Putredinis, and the impact crater small enough that the molten zone did not include the underlying Apennine Bench or Imbrium floor material.

A strong candidate source crater is Hadley $\mathrm{C}$, which is 5.5 $\mathrm{km}$ in diameter and $0.8 \mathrm{~km}$ deep. It is centered about 5 crater diameters southwest of the collection point of regolith 15434 at $25^{\circ} 25^{\prime} \mathrm{N}, 2^{\circ} 20^{\prime} \mathrm{E}$ (Fig. 14). It is the largest crater wholly within mare materials and in Palus Putredinis. Hadley $\mathrm{C}$ is by far the largest crater wholly within mare within several hundred kilometers of the collection site. It postdates Hadley Rille and the local mare, but lacks rays. Although it has a sharp bottom and smooth conical profile, it is an unusual crater in that it is difficult to distinguish on radar maps and is free of blocks and rock fragments (Zisk et al., 1971). There is no stratigraphic evidence precluding an age of $1647 \mathrm{Ma}$. There is no particular evidence that basalts younger than those at the Apollo 15 landing site exist around Hadley $\mathrm{C}$, thus suggesting that the singular basalts are part of the pile beneath thin olivine-normative basalts. However, the presence of younger materials there cannol be eliminated. Two smaller craters that occur as a pair further out in Palus Putredinis at $26^{\circ} 40^{\prime} \mathrm{N}, 2^{\circ} 15^{\prime} \mathrm{E}$, each less than $2 \mathrm{~km}$ across (Fig. 14), are also candidates based upon chemical considerations. They are obviously less capable of having ejecta emplaced at the Apennine Front than is Hadley $\mathrm{C}$.

\section{EXPOSURE AGE OF 15434,28 .}

Although sample 15434,28 solidified $1647 \mathrm{Ma}$ ago, it remains in its original spherical form. It appears to lack zap pits, spalls, or patina. Had it been constantly subjected to the severe gardening of the uppermost regolith, it would have been destroyed. Thus, it must have spent most of its lifetime buried in the regolith. We have calculated ${ }^{38} \mathrm{Ar}$ cosmic-ray exposure (CRE) ages for the glass spherule for various shielding depths (Table 5). After correcting the "Ar/ $\mathrm{Ar}$ ratios for reactorinduced isotopes, the "Ar and ${ }^{36} \mathrm{Ar}$ were partitioned between cosmogenic (cos) and trapped components as follows: If the corrected ${ }^{36} \mathrm{Ar} /{ }^{34} \mathrm{Ar}$ was more than 0.67 (the cosmogenic value), then it was assumed to be a two-component mixture of cosmogenic and trapped argon; if the corrected ${ }^{36} \mathrm{Ar} /{ }^{38} \mathrm{Ar}$ was less than 0.67 then ${ }^{31} \mathrm{Ar}_{6}$ was assumed to be present and all of the "Ar was assumed to be cosmogenic. For sample 15434,28, the reactor-corrected ${ }^{31} \mathrm{Ar}{ }^{3 / 4} \mathrm{Ar}$ ratios are very close to 0.67 , indicating that neither trapped argon nor ${ }^{8 \mathrm{~A}} \mathrm{Ar}_{\mathrm{C}}$ are present in significant amounts. For the seventeen plateau increments, the ${ }^{34} \mathrm{Ar}_{\text {cool }}{ }^{37} \mathrm{Ar}_{\mathrm{C}: \mathrm{i}}$ ratios show very little variation and have a mean value of $0.01051 \pm 0.00034(2 \sigma)$.

The biggest uncertainty in CRE ages based on the production of ${ }^{36} \mathrm{Ar}$ is the production rate, which varies with sample composition and with depth below the lunar surface (shielding). We have used our measured ${ }^{3 \times} \operatorname{Ar}_{1,1} /{ }^{37} \operatorname{Ar}{ }^{\circ}$ value for the plateau increments, the $\mathrm{Ca}, \mathrm{K}, \mathrm{Fe}$, and Ti contents of the glass (Table 3), and the values of Hohenberg et al. (1978) for the ${ }^{3 *} \mathrm{Ar}_{\mathrm{c}, \mathrm{m}}$ production rates from $\mathrm{Ca}, \mathrm{K}, \mathrm{Fe}$, and $\mathrm{Ti}$ at various shielding depths to calculate the CRE ages (Table 5). The glass 15434,28 came from a loosely consolidated clod of regolith that formed the pedestal at Spur Crater upon which anorthosite 15415 was found. The depth of the glass sphere within this clod is unknown, but the dimensions of the clod indicate that it was probably from 1 to $5 \mathrm{~cm}$. Our CRE ages for shiclding depths of 0 to $5 \mathrm{~g} / \mathrm{cm}^{2}$ (about 0 to $2.5 \mathrm{~cm} \mathrm{depth}$ ) show that 15434.28 could not have resided that near the lunar surface for the entire time since its formation. The CRE age of $6753 \mathrm{Ma}$ for $500 \mathrm{~g} / \mathrm{cm}^{2}$ (about $2.5 \mathrm{~m}$ using a regolith density of $1.5 \mathrm{~g} / \mathrm{cm}^{2}$ ) shows that 15434,28 also could not have been recently excavated from any substantial depth.

The precise age of Spur Crater is not known. Argon and krypton CRE ages on 15415 range from 90 to 104 Ma but also indicate a multistage exposure history (Husain, 1974; Eugster et al., 1984). Other rocks found on the rim of Spur Crater have CRE ages of about $250 \mathrm{Ma}$, and a few have exposure ages of about 50) Ma (Stettler et al., 1973; Bernstein, 1983; Husain, 1974). Spur Crater was excavated into a slope on the Apennine Front and its youthful form on suggests that it is relatively young. We do not know the exposure history of 15434,28 , but if it resided at a single depth between the time of its formation and its excavation and was only recently brought to within a few centimeters of the lunar surface, where it was found, then its residence depth could not exceed about $2 \mathrm{~m}$.

\section{CONCLUSIONS}

Sample 15434,28 is a coarse-fines $(4-10 \mathrm{~mm})$ particle from the regolith collected on the Apennine Front. It was collected as an unbroken spherule of glass $6 \mathrm{~mm}$ in diameter with a thin fragment-bearing rind. Its petrographic and chemical characteristics and its chronology suggest an impact origin, but a volcanic origin cannot be precluded. The glass formed $1647 \pm 11 \mathrm{Ma}$ ago. It is of a nearly pure mare composition, with at most about 0.1 wt $\%$ meteoritic contamination or less than $2 \mathrm{wt} \%$ regolith contamination. The mare composition is distinct, with the major element, $\mathrm{Sc}, \mathrm{Ni}$, and $\mathrm{Co}$ abundances typical of a low-Ti mare basalt yet the incompatible element and $\mathrm{Sr}$ abundances typical of a high-Ti mare basalt. However, the chemical compostion cannot be formed from mixtures of these basalt types. Nor can any recognized KREEP rock type contribute significantly to the chemical characteristics. The relative abundances of the trace elements are unique among analyzed lunar samples. If the glass is of impact origin, the target was an extremely immature mare terrain composed of previously unrecognized basalts. The target might have consisted of a single mare hasalt type. The chemical composition of minerals and volcanic glass fragments in the rind suggest a source near the Apollo 15 landing area; Hadley $\mathrm{C}$, about 25 $\mathrm{km}$ away, is a strong candidate for the parent crater.

Acknowledgments - We appreciate Rene Martinez, David Mittelfehldt, and Vincent Yang of Lockheed at the Johnson Space Center for their necessary assistance in neutron activation and microprobe analyses. We also appreciate David Vaniman and James Papike for supplying their unpublished microprobe information on 15434,28. Reviews and comments by David Vaniman, Clive Neal, lan Ridley, and Chris Koeherl contributed to improving the revised manuscript. This work was done with support to the authors from the NASA Planetary Materials and Geochemistry Program. The Lunar and Planetary Institute is operated by the Universities Space Research Assocation under contract NASW-4066 with the National Aeronatics and Space Administration. This paper is Lunar and Planetary Institute Contribulion \# 877

Editorial handling: (.. Koeberl 


\section{REFERENCES}

Arndt J. and von Engelhardt W. (1987) Formation of Apollo 17 orange and black glass beads. Proc. 17th Lunar Planet. Sci. Conf.; J. Geophys. Res. 92, E372-E376.

Arndt J., Flad K., and Feth M. (1979) Radiative cooling experiments on lunar glass analogs. Proc. 10th Lunar Planet. Sci. Conf., 355373.

Arndt J., von Engelhardt W., Gonzalez-Chabeza I., and Meier B. (1984) Formation of Apollo 15 green glass beads. Proc. 15th Lunar Planet. Sci. Conf.; J. Geophys. Res. 89. C225-C232.

Baedecker P. A., Chou C.-L., Grudewiicz E. B., and Wasson J. T. (1973) Volatile and siderophilic trace elements in Apollo 15 samples: Geochemical implications and characterization of the longlived and short-lived extralunar components. Proc: 4th Lunar Sci. Conf. 1177-1195.

Basu A., McKay D. S., Moore C. H., and Shaffer, N. R. (1979) A note on the Apollo 15 green glass vitrophyres. Proc. 10th Lunar Planet. Sci. Conf., 301-310.

Basaltic Volcanism Study Project (1981) Basaltic Volcanism on the Terrestrial Planets. Pergamon Press.

Bernstein M. L. (1983) 15445 and 15455: Origin and preliminary age data. Lunar Planet. Sci. XIV, 33-34 (abstr.).

Bottinga Y. and Weill D. (1972) The viscosity of magmatic silicate liquids: A model for calculation. Amer. J. Sci. 272, 438-476.

Busche F. D., Conrad G. H., Keil K., Prinz M., Bunch T. E., Erlichman J.. and Quaide W. L. (1971) Electron microprobe analyses of minerals from Apollo 12 lunar samples. Special Publication Number 3, Univ. New' Mexico Inst. of Meteoritics.

Butler P. (1972) Compositional characteristics of olivines from Apollo 12 samples. Geochim. Cosmochim. Acta 36, 773-785.

Carmichael I. S. E., Nicholls J., Spera F. J., Wood B. J., and Nelson S. A. (1977) High-temperature properties of silicate liquids: Applications to the equilibration and ascent of basic magma. Phil. Trans. Roy. Soc. London A286, 373-431.

Dalrymple G. B. (1989) The GLM continuous laser system for ${ }^{41} \mathrm{Ar} /$ ${ }^{30} \mathrm{Ar}$ dating: Description and performance characteristics. In New Frontiers in Stable Isotope Research (ed. W. C. Shanks III and R. E. Criss); USGS Bull. 1890, 89-96.

Dalrymple G. B. and Duffield W. A. (1988) High precision ${ }^{41} \mathrm{Ar} /{ }^{39} \mathrm{Ar}$ of Oligocene rhyolites from the MogollanDatil volcanic field using a continuous laser system. Geophys. Res. Lett. 15, 463-466.

Dalrymple G. B. and Ryder G. (1993) ${ }^{40} \mathrm{Ar} /{ }^{30} \mathrm{Ar}$ age spectra of Apollo 15 impact melt rocks by laser step-heating and their bearing on the history of lunar basin formation. J. Geophys. Res. 98, 13,08513,095 .

Delano J. (1979) Apollo 15 green glass: Chemistry and possible origin. Proc. 1Oth Lunar Planet. Sci. Conf., 275-300.

Delano J. (1980) Chemistry and liquidus phase relations of Apollo 15 red glass: Implications for the deep lunar interior. Proc. $1 \mathrm{lh}$ Lunar Planet. Sci. Conf., 251-288.

Delano J. (1986) Pristine lunar glasses: Criteria, data, and implications. Proc. I6th Lunar Planet. Sci. Conf.; J. Geophys. Res. 91, D201-D213.

Delano J. and Livi K. (1981) Lunar volcanic glasses and their constraints on mare petrogenesis. Geochim. Cosmochim. Acta 45, 2137-2149.

Delano J., Lindsley D., Ma M.-S., and Schmitt R. A. (1982) The Apollo 15 yellow impact glasses: Chemistry, petrology, and exotic origin. Proc. 13th Lunar Planet. Sci. Conf.; J. Geophys. Res. 87, A $159-A 170$

Delano J., Sutton S. R., and Smith J. V. (1991) Lunar volcanic glasses: Trace element abundances in individual spheres using synchrotron X-ray fluorescence. Lunar Planet. Sci. XXII, 311-312 (abstr.).

Dickinson T., Taylor G. J., Keil K., Schmitt R. A., Hughes S. S., and Smith M. R. (1985) Apollo 14 aluminous mare basalts and their possible relationship to KREEP. Proc. 15th Lunar Planet. Sri. Conf.; J. Geophys. Res. 90, C365-C374.

Dowty E., Prinz M., Nehru C. E., Moreland G., Moore R. B., Keil K., Hlava P. F., and Green J. A. (1973) Elecron microprobe analyses of minerals from Apollo 15 mare basalt rake samples. Special Publication Number 93, Univ. New Mexico Inst. of Meteoritics.
Ebihara M., Warren P. H., and Anders E. (1992) Trace elements in 59 mostly highland Moon rocks. Proc. Lunar Planet Sci. 22, $417-$ 426.

Eugster O., Eberhardt P., Geiss J., Grögler N., Jungck M., Meier F., Mörgeli M., and Niederer F. (1984) Cosmic ray exposure histories of Apollo 14. Apollo 15, and Apollo 16 rocks. Proc. 14th Lunar Planet. Sci. Conf.: J. Geophys. Res. 89, B498-B512.

Haskin L. and Warren P. H. (1991) Lunar Chemistry. In Lunar Sourcebook (ed. G. H. Heiken et al.). Chapter 8, pp. 357-474. Cambridge Univ. Press.

Heiken G. (1972) Morphology and petrography of volcanic ashes GSA Bull. 83, 1961-1988.

Hohenberg C. M., Marti K., Podosek F. A., Reedy R. C., and Shirck J. R. (1978) Comparisons between observed and predicted cosmogenic noble gases in lunar samples. Proc, 9th Lunar Planer. Sci. Conf., 2311-2344

Husain L. ( 1974$)^{40} \mathrm{Ar} /{ }^{34} \mathrm{Ar}$ chronology and cosmic ray exposure ages of the Apollo 15 lunar samples. J. Geophys. Res. 79. 2588-2606.

Lange R. A. and Carmichael I. S. E. (1987) Densities of $\mathrm{Na}_{2} \mathrm{O}-\mathrm{K}_{2} \mathrm{O}$ $\mathrm{CaO}-\mathrm{MgO}-\mathrm{FeO}-\mathrm{Fe}_{2} \mathrm{O}_{3}-\mathrm{Al}_{2} \mathrm{O}_{1}-\mathrm{TiO}_{2}-\mathrm{SiO}_{2}$ liquids: $\mathrm{New}$ measurements and derived partial molar properties. Geochim. Cosmochim. Acta 51, 2931--2946.

Lanphere M. A., Dalrymple G. B., Fleck R. J., and Pringle M. S (1990) Intercalibration of mineral standards for $\mathrm{K}-\mathrm{Ar}$ and ${ }^{311} \mathrm{Ar} / \mathrm{Ar}$ age measurements. Eos Trans. AGU 71, 1658.

Lindstrom M. M., Marvin U. B., and Mittlefehldt D. W. (1989) Apollo $15 \mathrm{Mg}$ - and Fe-norites: A redefinition of the $\mathrm{Mg}$-suite differentiation trend. Proc. 19th Lunar Planet. Sci. Conf., 245-254.

McGee J. J. (1993) Lunar ferroan anorthosites: Mineralogy, compositional variations, and petrogenesis. J. Geophys. Res. 98,9089 9105.

Neal C. R., Taylor L.A, and Lindstrom M. M. (1988) Apollo 14 mare basalt petrogenesis: Assimilation of KREEP-like components by a fractionating magma. Proc. 18th Lunar Planet. Sci. Conf., 139 153.

Neal C. R., Taylor L. A., Schmitt R. A.. Hughes S. S., and Lindstrom M. M. (1989) High-alumina (HA) and Very High Potassium (VHK) basalt clasts from Apollo 14 breccias, Part 2 - Whole rock geochemistry: Further evidence for combined assimilation and fractional crystallization within the lunar crust. Proc. 19th Lunar Planet. Sci. Conf., 147-161.

Norman M. and Ryder G. (1980) Geochemical constraints on the igneous evolution of the lunar crust. Proc. 1/th Lunar Planet. Sci. Conf., 317-331.

Papike J., Taylor L., and Simon S. (1991) Lunar minerals. In Lunar Sourcebook (ed. G. H. Heiken et al.), Chapter 5, pp. 12I-181 Cambridge Univ. Press.

Phinney W., Warner J. L., Simonds C. H., and Lofgren G. E. (1972) Classification and distribution of rock types at Spur Crater. In The Apollo 15 Lunar Samples (ed. J. W. Chamberlain and C. Watkins), pp. 149-153. The Lunar Science Institute, Houston.

Powell B. (1972) Apollo 15 Coarse Fines (4-10 mm): Sample Classification, Description, and Inventory. NASA Manned Spacecraft Document MSC 03288.

Ryder G. (1986) Analyses of Apollo 15 green glasses: Groupings and their spatial relationships. Lunar Planet. Sci. XVII, 738-39 (abstr.).

Ryder G. (1990a) A 6-mm glass sphere from the Apennine Front: An exceptional volcanic glass (or just a remarkable impact glass?). In Lunar and Planetary Institute Tech. Rept. 90-02, pp. 54-55.

Ryder G. (1990b) Origin of a $6 \mathrm{~mm}$ glass sphere from the Apennine Front: Debris in the rind. Lunar Planet. Sci. XXI, 1057-1058 (abstr.).

Ryder G. (1990c) A distinct variant of high-titanium mare basalt from the Van Serg core. Apollo 17 landing site. Meteoritics 25, 249 258.

Ryder G. and Burling T. C. (1996) An Apollo 15 mare basalt fragment and lunar mare provinces. Meteor. Planet. Sci. (in press).

Ryder G. and Sherman S. B. (1989) The Apollo 15 Coarse Fines (4$10 \mathrm{~mm}$. NASA Johnson Space Center JSC 24035.

Ryder G., Bogard D., and Garrison D. (1991) Probable age of Autolycus and calibration of lunar stratigraphy. Geology 19 , $143-146$. 
Salpas P. A., Taylor L. A., and Lindstrom M. M. (1987) Apollo 17 KREEPy basalts: Evidence for non-uniformity of KREEP. Proc: 17th Lunar Planet. Sci. Conf.; J. Geophys. Res. 92. E340-E348.

Shervais J. W., Taylor L. A., and Lindstrom M. M. (1985a) Apollo 14 mare basalts: Petrology and geochemistry of clasts from consortium breccia 14321. Proc. ISth Lunar Planet. Sci. Conf.; J. Geophys. Res. 89, C375-C395.

Shervais J. W., Taylor L. A., Laul J. C., Shih C.-Y., and Nyquist L. E. (1985b) Very high potassium (VHK) basalt: Complications in mare basalt petrogenesis. Proc. Ioth Lunar Planet. Sci. Conf.; J. Geophys. Res. 90, D3-18.

Spangler R. R. and Delane J. (1984) History of the Apollo 15 yellow impact glass and sample 15426 and 15427. Proc. 14th Lunar Planet. Sci. Conf:; J. Geophys. Res. 89, B478-B486.

Spangler R. R.. Warasila R., and Delano J. (1984) ${ }^{46} \mathrm{Ar} /{ }^{14} \mathrm{Ar}$ ages of the Apollo 15 green and yellow volcanic glasses. Proc. I4th Lunar Planet. Sci. Conf: J. Geophys, Res. 89, B487-B497.

Stettler A., Eberhardt P., Geiss J., Grögler N., and Maurer P. (1973) ${ }^{40} \mathrm{Ar}-{ }^{39} \mathrm{Ar}$ ages and ${ }^{37} \mathrm{Ar}-{ }^{38} \mathrm{Ar}$ exposure ages of lunar rocks. Proc. 4th Lunar Sci. Conf., 1865-1888.

Taylor G. J., Wentworth S., Warner, R. D., Keil K., Ma M.-S., and Schmitt R. A. (1980) Major-element compositional variations of KREEP. Lunar Planet. Sci. XI, 1131-1133 (abstr.).
Taylor G. J., Warren P., Ryder G., Delano J., Pieters C., and Lofgren G. (1991) Lunar Rocks. In Lunar Sourcebook (ed. G. H. Heiken et al.), Chap. 6, 183-294. Cambridge Univ. Press.

Wänke H., Baddenhausen H., Dreibus G., Jagoutz E., Kruse H, Spettel B., and Teschke F. (1973) Multielement analyses of Apollo 15 16, and 17 samples and the bulk composition of the Moon. Proc. 4th Lunar Sci. Conf. 1461-1481.

Warren P. and Kallemeyn G. W. (1993) Geochemical investigation of two lunar mare meteorites: Yamato-793169 and Asuka-881757 Proc. NIPR Symp. Antarct. Meteorites, No. 6, 35-37.

Warren P., Shirley D. N., and Kallemeyn G. W. (1986) A potpourri of pristine moon rocks, including a VHK mare basalt and a unique, augite-rich Apollo 17 anorthosite. Proc. I6th Lunar Planer. Sci. Conf:; J. Geophys. Res. 91, D319D330.

Whitford-Stark J. L. and Head J. W. (1980) The stratigraphy of Mare Imbrium. Lunar Planet. Sci. XI, 1245-1247 (abstr.).

Wilhelms D. (1987) The Geologic History of the Moon. USGS. Professional Paper 1.348.

Zisk S., Carr M. H., Masursky H., Shorthill R. W., and Thompson T. W. (1971) Lunar Apennine-Hadley region: Geological implications of Earth-based radar and infrared measurements. Science 173, 808-812 